\title{
Grazing by protists and seasonal changes in the size structure of protozooplankton and phytoplankton in a temperate nearshore environment (western Gulf of St. Lawrence, Canada)
}

\author{
E. Tamigneaux ${ }^{1}$, M. Mingelbier ${ }^{2}$, B. Klein ${ }^{2, *}$, L. Legendre ${ }^{2}$ \\ ${ }^{1}$ Département des Sciences biologiques, Université du Québec à Montréal, CP 8888, Montréal, Québec, Canada H3C 3P8 \\ ${ }^{2}$ Département de Biologie, Université Laval, Québec, PQ, Canada G1K 7P4
}

\begin{abstract}
Seasonal changes in the biomass and size structure of phytoplankton and protozooplankton and the grazing effect of protozooplankton on phytoplankton were assessed in a temperate nearshore environment (Baie des Chaleurs, western Gulf of St. Lawrence, Canada). The size structure of protozooplankton and phytoplankton assemblages showed relatively similar seasonal changes. During spring, dominance by large $(>20 \mu \mathrm{m})$ heterotrophic or mixotrophic ciliates and flagellates coincided with high biomass of chain-forming diatoms, suggesting that protists were important grazers of the spring diatom bloom. During summer, concentrations and biomass of ciliates and flagellates $>20 \mu \mathrm{m}$ were lower than they were during spring and, consequently, the relative contribution of protists $<20 \mu \mathrm{m}$ increased. The potential grazing impact of ciliates $<20 \mu \mathrm{m}$ on single celled cyanobacteria was similar to or even higher than that of nanoflagellates. Grazing experiments conducted in situ using the serial dilution technique and pre-screening water on $64 \mu \mathrm{m}$ showed that 33 to $42 \%$ of the chl a biomass and 54 to $>100 \%$ of phytoplankton production were consumed daily by protozooplankton. Thus, when predation was reduced, protozooplankton were able to control phytoplankton biomass and production. Predation by copepods, which showed high concentrations and were dominated by omnivorous Oithonidae during summer, may have played a central role in the seasonal changes in the size structure and biomass of protozooplankton. The observations and results from path analysis suggest the existence of 2 different food webs corresponding to bloom and summer conditions, respectively.
\end{abstract}

KEY WORDS: Size structure Protozooplankton Ciliates Flagellates Grazing Phytoplankton Temperate nearshore waters

\section{INTRODUCTION}

There is increasing evidence that the microbial food web is a fundamental and almost permanent feature of most oligotrophic and eutrophic marine waters. Some authors now refer to this food web as a maintenance system (Riegman et al. 1993). In the microbial food web, mixotrophic and heterotrophic nanoflagellates and ciliates $<20 \mu \mathrm{m}$ are major predators of bacteria and cyanobacteria (Bernard \& Rassoulzadegan 1990, Capriulo 1991). These protozoan grazers are in turn the prey of ciliates $>20 \mu \mathrm{m}$ and dinoflagellates, which

·E-mail: bert.klein@giroq.ulaval.ca also consume nanoplanktonic and sometimes microplanktonic algae (Capriulo 1990, Pierce \& Turner 1992). While most metazoan zooplankton are relatively inefficient at capturing bacterial-sized prey, some are able to feed on protozooplankton (Stoecker \& Capuzzo 1990, Sanders \& Wickham 1993). The latter thus can act as a link between the smallest members of the microbial food web and larger organisms. In addition, it is generally considered that the high growth rates of protozooplankton should enable them to control assemblages of bacterioplankton and small phytoplankton, at least when temperature does not limit their growth and when predation by metazoa is low (Havens 1993, Riegman et al. 1993). 
Although some protozoan grazers can feed on phytoplankton larger than themselves (e.g. Hansen 1992), it has been demonstrated that protozoa have specific minimum, optimum, and maximum prey sizes, which are generally smaller than themselves (Rassoulzadegan et al. 1988, Lessard 1991). In temperate marine waters, seasonal shifts in the size distributions of autotrophic organisms generally occur throughout the year, between dominance by large cells during the spring and autumn phytoplankton blooms and dominance by ultraplankton during summer and winter (e.g. Durban et al. 1975, Claereboudt et al. 1994). These shifts are likely to influence the size distributions of protozooplankton assemblages and, hence, the overall structure and functioning of the microbial food web. However, there is little information available on changes in the size structure of heterotrophic ciliate and flagellate assemblages in temperate waters. Until recently, most of the data reported on protozooplankiton were for organisms in the 20 to $200 \mu \mathrm{m}$ size range (microzooplankton). For example, the biology of tintinnids (typically 40 to $200 \mu \mathrm{m}$ ) has been widely studied, whereas the distribution and grazing significance of the more delicate aloricate ciliates, particularly forms $<20 \mu \mathrm{m}$, remain poorly investigated in marine waters (Pierce \& Turner 1992).

Since protozooplankton, especially ciliates, are known to be more abundant in nearshore waters than in the open sea (Campbell \& Carpenter 1986, Pierce \& Turner 1992), it follows that their role in food webs of nearshore marine waters is expected to be particularly important. However, although the significance of herbivorous protists to the fate of primary production is now widely recognised (Sherr \& Sherr 1994), their grazing effects on natural plankton assemblages of temperate nearshore waters are still poorly known. Many studies on the grazing of herbivorous protists have been conducted under controlled laboratory conditions, often using monospecific cultures, so that the amount of data available on specific clearance rates of various protist species is increasing (e.g. Bernard \& Rassoulzadegan 1990, Verity 1991, Hansen 1992). In contrast, field studies have generally used the serial dilution method of Landry \& Hassett (1982) to determine the grazing activities of microzooplankton assemblages (e.g. Paranjape 1990, Weisse \& ScheffelMöser 1990, McManus \& Ederington 1992). In these studies, in addition to herbivorous protozod, the latter included small metazoan plankters such as copepod nauplii and planktonic larvae of benthic organisms (e.g. bivalves and crustaceans). Since these metazoan organisms can act as competitors and predators of herbivorous protists, it follows that grazing rates determined in such studies generally reflect complex herbivorous and carnivorous interactions (Verity et al. 1993, Sime-Ngando et al. 1995).
The aims of the present study were (1) to examine seasonal changes in the size distributions of ciliate and flagellate assemblages in relation to the size distribution of their potential food (i.e. phytoplankton) and the potential effects of their predators (i.e. mesozooplanktonj and (2) to assess the intensity of grazing by protozooplankton on phytoplankton, in the absence of metazoan competitors or predators, using in situ incubations of water passed through a $64 \mu \mathrm{m}$ mesh. In the present study, special emphasis was put on the smallest forms of ciliates and flagellates.

\section{MATERIALS AND METHODS}

Sampling. The study was conducted in the Baie des Chaleurs (western Gulf of St. Lawrence, Canada) from May to October in 1991 and 1992. The sampling station was located at Gascons, on the Québec shore of the bay $\left(48^{\circ} 10.60^{\prime} \mathrm{N}, 64^{\circ} 54.80^{\prime} \mathrm{W}\right)$. The station (22 $\mathrm{m}$ depth, ca $1.8 \mathrm{~km}$ offshore) was occupied weekly, always during high tide to minimise variability due to tides. When primary production measurements were performed, additional samples were taken at dawn for determination of chlorophyll a (chl a) and nutrient concentrations, and additional CTD profiles were carried out, independent of the tidal cycle, in order to follow the recommendation of JGOFS (1988) for conducting of $24 \mathrm{~h}$ dawn-to-dawn in situ primary production incubations.

Water was collected using an 81 Niskin bottle at 4 depths $(1,5,9$ and $21 \mathrm{~m})$ in 1991 and 5 depths $(1,5,9$, 15 and $21 \mathrm{~m}$ ) in 1992. All water samples were prefiltered through a $200 \mu \mathrm{m}$ Nitex mesh and stored in isothermal containers until they were processed. Processing occurred within $2 \mathrm{~h}$ of collection. Temperature and salinity profiles were recorded with a CTD instrument (SBE 19, Seabird Electronics Inc., Bellevue, WA, USA). During summer 1992, several oblique tows were taken from bottom to surface, using a $64 \mu \mathrm{m}$ net, to determine the composition of mesozooplankton assemblages

Treatment of water samples. Water samples (250 ml) for determination of chl $a$ and phaeopigment (Phaeo) were size-fractionated using 3-compartment Nuclepore ${ }^{\infty}$ Swin-Lok $47 \mathrm{~mm}$ filter towers, with a $20 \mu \mathrm{m}$ Nitex filter at the top, a $5 \mu \mathrm{m}$ Nitex filter in the middle, and a Whatman GF/F filter at the bottom. Chl a retention properties of glass-fiber GF/F filters are similar to those of $0.2 \mu \mathrm{m}$ membrane filters (Chavez et al. 1995). Filtration provided 3 size fractions, i.e. $0.2-5 \mu \mathrm{m}, 5-20 \mu \mathrm{m}$, and 20-200 $\mu \mathrm{m}$. However, since seasonal changes in the size fractions 5-20 $\mu \mathrm{m}$ and 20-200 $\mu \mathrm{m}$ were similar and the size fraction $5-20 \mu \mathrm{m}$ was generally $<10 \%$ of the total 
chl a biomass, these 2 size fractions were pooled and are referred to in this paper as the $>5 \mu \mathrm{m}$ fraction. Filtration was under vacuum pressure $<100 \mathrm{~mm} \mathrm{Hg}$. Filters for chl a and Phaeo were kept at $-20^{\circ} \mathrm{C}$ until analysis. They were subsequently extracted in $90 \%$ acetone during $24 \mathrm{~h}$ in the dark at $0^{\circ} \mathrm{C}$, and pigment concentrations were determined with a Turner Fluorometer 112 using the fluorometric method of Yentsch \& Menzel (1963) and following the procedures given by Parsons et al. (1984).

During the 1992 sampling season, several primary production measurements were conducted in situ, from dawn to dawn, together with the grazing experiments. Nalgene $250 \mathrm{ml}$, acid-cleaned tissue culture flasks were filled with seawater from each sampling depth and inoculated with $10 \mu \mathrm{Ci} \mathrm{H}^{14} \mathrm{CO}_{3}^{-}$. At each of the 5 sampling depths, 2 dark and 2 light bottles were incubated horizontally for $24 \mathrm{~h}$ (dawn to dawn) using a plexiglass frame. Processing of the samples followed the procedure described in Tamigneaux et al. (1995).

Water for determination of nitrate, nitrite, and phosphate was filtered on Whatman GF/F filters before analysis. To avoid possible contamination, water for determination of silicate was not filtered. All nutrient samples were frozen $\left(-20^{\circ} \mathrm{C}\right)$ in 4 -ml cryovials. Analyses were on a Alpkem AutoAnalyzer (Alpkem Inc., Wilsonville, OR, USA), following the colorimetric methods of Parsons et al. (1984).

Grazing experiments. In order to estimate the grazing of phytoplankton by protozooplankton, 7 experiments were performed between May and August 1992, using the dilution method of Landry \& Hassett (1982). Diluted samples were incubated at $5 \mathrm{~m}$ depth at the sampling site, over $24 \mathrm{~h}$ from dawn to dawn. The day before each experiment, 351 of seawater from $5 \mathrm{~m}$ depth was brought to the laboratory and filtered, first through a Whatman GF/F filter and then through a Gelman $0.2 \mu \mathrm{m}$ 'minicapsule' filter. The particle-free water was kept at $10^{\circ} \mathrm{C}$ in darkness until further processing. On the day of the experiments, 5 dilution mixtures (2 l) were prepared with freshly sampled water from $5 \mathrm{~m}$ depth and the particle-free seawater, at ratios of $100: 0,90: 10,80: 20,60: 40,20: 80$ and $0: 100$ (particle-free control; Li 1990). Each treatment (i.e. each dilution mixture and undiluted control) was gently poured through an immersed $64 \mu \mathrm{m}$ mesh in order to eliminate the smallest metazoa, e.g. copepod nauplii and copepodites. Finally, acid-cleaned, glass reagent bottles (1 l) were filled to the brim with each treatment and sealed carefully in order to exclude air bubbles. At the beginning and end of each experiment, samples for chl a $(250 \mathrm{ml})$ and protozooplankton enumeration $(100 \mathrm{ml})$ were taken from each dilution treatment. Only chl a was determined for the particle-free control.
Nutrient concentrations were determined for the undiluted sample at the start and end of the $24 \mathrm{~h}$ incubation in order to identify possible nutrient limitation over the 24 h time span.

The apparent growth rate $(k)$ of chl $a$ in individual bottles was calculated using the exponential model given by Landry \& Hassett (1982):

$$
P_{1}=P_{0} \exp [k-g] t
$$

where $P_{0}$ and $P_{t}$ are chl a concentrations at the beginning and end of the experiment, respectively; $k$ and $g$ are instantaneous coefficients $\left(\mathrm{d}^{-1}\right)$ of phytoplankton growth and grazing mortality, respectively; $t$ is time (d). Coefficients $k$ and $g$ were determined from linear regression of the apparent growth rate of phytoplankton $\left(1 / t \ln \left[P_{t} / P_{0}\right]\right)$ on the fraction of undiluted seawater. The negative slope of the line is the daily grazing coefficient $(g)$ and the $y$-intercept is the phytoplankton growth rate $(k)$. The null hypothesis $\left(\mathrm{H}_{0}\right) g=0$ was t-tested. Results from the serial dilution experiments were used to calculate the numbers of doublings per day of phytoplankton (Antia 1991):

$$
\text { Doublings } \mathrm{d}^{-1}=\frac{k}{\ln 2}
$$

These were compared with estimates derived from chl a and primary production, calculated using the following formula (Antia 1991):

$$
\text { Doublings } \mathrm{d}^{-1}=\frac{\text { Primary production }\left(\mu \mathrm{g} \mathrm{Cl}^{-1} \mathrm{~d}^{-1}\right)}{\left[\mathrm{chl} a\left(\mu \mathrm{gl}^{-1}\right) \times 40\left(\mu \mathrm{g} \mathrm{C} \mu \mathrm{g}^{-1} \mathrm{chl} \mathrm{a}\right)\right]}
$$

Laboratory measurements. In 1992, samples (100 ml) for enumeration of ultraphytoplankton $(<5 \mu \mathrm{m})$ were fixed with paraformaldehyde $(0.2 \%$ final conc.) and stored for at least $1 \mathrm{~h}$ in the dark at $5^{\circ} \mathrm{C}$ before further processing. Phototrophic eucaryotes $<5 \mu \mathrm{m}$ and cyanobacteria were enumerated under the epifluorescence microscope and their carbon biomasses were estimated following the procedure described in Tamigneaux et al. (1995). In 1991 and 1992, samples $(250 \mathrm{ml})$ for enumeration of phytoplankton $>5 \mu \mathrm{m}$ and protozooplankton were preserved with $1 \%$ (vol:vol) acidic Lugol's solution. Within $6 \mathrm{mo}, 100 \mathrm{ml}$ subsamples were sedimented over $30 \mathrm{~h}$ before enumeration under the inverted microscope (Lund et al. 1958). Magnification was chosen according to cell size, i.e. $600 x$ for cells less than $20 \mu \mathrm{m}, 300 \times$ for cells $20-50 \mu \mathrm{m}$, and $100 \times$ for larger organisms. In 1992, samples for the determination of mesozooplankton $(500 \mathrm{ml})$ were preserved with buffered $5 \%$ formalin.

Lugol's iodine is recognised as a good fixative for accurately estimating ciliate biomass (Jerome et al. 1993). However, there are limitations to the use of this preservative for protozooplankton, i.e. identification of protists to species level is difficult and discrimination be- 
tween heterotrophic and autotrophic forms is not always possible. Distinguishing between strict phototrophs, mixotrophs, and strict heterotrophs using epifluorescence microscopy would have been valuable. However, while the presence of chlorophyll fluorescence in flagellates may indicate phototrophy, it is not proof (see Stoecker 1991 on chloroplast enslavement). In addition, the trophic status of most dinoflagellates (Larsen \& Sournia 1991) and nanoflagellates (Capriulo et al. 1991, Hall et al. 1993) is under revision, since many phytoflagellates now appear to be mixotrophic (Jones 1994). The trophic status of the identified dinoflagellate genera was set according to Larsen \& Sournia (1991). Among planktonic ciliates, Myrionecta rubrum, which is easily identified, is the only species known to be strictly autotrophic, whereas others are considered mixotrophic or heterotrophic (Pierce \& Turner 1992),

During the seasonal survey of 1991, protozooplankton were only identified into broad taxonomic groups, i.e. aloricate choreotrich ciliates, choreotrich ciliates with a lorica (tintinnids), and microflagellates. Cell dimensions were not measured. In 1992, protozooplankton were identified into species, genera, or broader taxonomic groups and cell dimensions were measured and cells separated into size classes $\quad<20$, $20-50$ and $>50 \mu \mathrm{m}$ ) for better estimating their trophic roles (Rassoulzadegan et al. 1988, Bernard \& Rassoulzadegan 1990). The term 'choreotrichs' refers herein to the subclass Choreotrichia in the phylum Ciliophora and it includes orders Choreotrichida and Oligotrichida (Montagnes \& Lynn 1991).

In order to determine protozoan cell volumes, the length and width of 50 cells of each taxonomic group were measured at $600 \times$ using a calibrated ocular micrometer. Cell volumes were determined by applying standard geometric shapes to cells. Carbon biomasses were calculated using a conversion factor of $0.15 \mathrm{pg} \mathrm{C} \mu^{-3}$ for flagellates (Sheldon et al. 1986) and $0.19 \mathrm{pg} \mathrm{C} \mathrm{m}^{-3}$ for ciliates (Putt \& Stoecker 1989).

Path analysis. Path analysis was used to elucidate the importance of direct links between protist abundances and concentrations of their potential food particles. Path analysis allows us to state hypotheses on causal relationships among variables and to assess the consequences of the assumed relationships using coefficients of linear regression and correlation computed among the variables (Sokal \& Rohlf 1981, Legendre \& Legendre 1984). Also, the percentages of non causal relationships (spurious correlations) associated with path coefficients can be computed. Path analysis was carried out using the $\mathrm{R}$ package for multivariate data analysis (Legendre \& Vaudor 1991). Path coefficients are interpreted by examining their signs and relative magnitudes, rather than using their individual statistical significance (Sokal \& Rohlf 1981)

\section{RESULTS}

\section{Oceanographic conditions}

Oceanographic conditions at the sampling station were discussed in detail by Tamigneaux et al. (1995). During the sampling seasons of 1991 and 1992, water temperature ranged from $0^{\circ} \mathrm{C}$ at the beginning of May to $15-20^{\circ} \mathrm{C}$ at the end of July and in August. Salinity ranged from 31 PSU at the beginning of May to 26 PSU at the end of June, when freshwater runoff was strong. The water column was generally stratified from the end of May to the end of August and the surface mixed layer seldom extended deeper than 5 to $10 \mathrm{~m}$ during this period.

For both years, the spring phytoplankton bloom was observed in May and June (Figs. 1 \& 2). At this time phytoplankton $>5 \mu \mathrm{m}$ accounted for $>60 \%$ of the total chl a biomass, which reached up to $20 \mathrm{mg} \mathrm{m}^{-3}$ The bloom was dominated by Chaetoceros spp. and Thalassiosira spp. in chains, with individual cells $\leq 30 \mu \mathrm{m}$. At the end of the bloom, chains of cells started to aggregate and there was massive sinkage of resulting flocculates to the bottom (observed by scientific SCUBA divers at the sampling site). During the summers of the 2 years, phytoplankton $<5 \mu \mathrm{m}$ accounted for $>90 \%$ of the total chl a biomass, which was generally $<2.5 \mathrm{mg} \mathrm{m}^{-3}$ (Figs. 1 \& 2). Concentrations of cyanobacteria reached their highest values during summer (Fig. 2b) and no colonial forms were observed throughout the season. Autumn blooms of phytoplankton (September and October) were somewhat less pronounced, with chl a concentrations $<7 \mathrm{mg} \mathrm{m}^{-3}$. The autumn phytoplankton bloom in October 1992 was dominated by thecate dinoflagellates Ceratium sp.

\section{Dynamics of protozoa in 1991}

Throughout the 1991 sampling season, protozoa were numerically dominated by flagellates 2 to $200 \mu \mathrm{m}$, with concentrations ranging from $2.2 \times 10^{3}$ to $5.6 \times$ $10^{6}$ cells $1^{-1}$ (mean $3.7 \times 10^{5}$ ) (Fig. 1c). Over the $22 \mathrm{~m}$ water column (areal concentrations), flagellated cells always accounted for ca $95 \%$ of the protozoan assemblage, the remaining $5 \%$ being ciliates (tintinnids and aloricate ciliates). During summer, the flagellate assemblage was almost entirely dominated by nanoflagellates. In the ciliate assemblage, aloricate choreotrichs were always dominant, with concentrations ranging from $1.2 \times 10^{2}$ to $2.8 \times 10^{4}$ cells $1^{-1}$ (average $4.5 \times 10^{3}$ ) (Fig. 1d). Tintinnids $\left(<10^{2}\right.$ to $1.9 \times 10^{3}$ cells $l^{-1}$, average $5.2 \times 10^{2}$ ) made up, on average, $19 \%$ of the ciliates, and were thus 4 times less abundant than the aloricate choreotrichs (Fig 1e). Throughout the sea- 
son, concentrations of both microflagellates and aloricate choreotrichs were always higher in the upper half of the water column $(0$ to $10 \mathrm{~m}$ ) than below (Fig. 1).

During the second fortnight of June, abundances of aloricate choreotrichs and tintinnids peaked in the upper part of the water column (Fig. 1d, e). The rapid increase in the concentration of ciliates corresponded to a peak concentration of chl $a$ in the $>5 \mu \mathrm{m}$ fraction, i.e. the spring diatom bloom (Fig, 1a, b). Following this peak, ciliates remained at low concentrations throughout the summer. Ciliate numbers started to increase again in autumn, when large phytoplankton resumed a dominant role. Flagellate numbers (Fig 1c) increased at the end of June after the ciliate peak, continued to rise through the end of July, and returned to low concentrations at the beginning of August, when a second peak of tintinnids occurred (Fig. 1e). From the end of the spring bloom, flagellates were numerically dominated by cells $<10 \mu \mathrm{m}$.

\section{Seasonal dynamics and size distributions} of protozoa in 1992

Since chl a biomasses and concentrations of protozoa were generally maximal near the surface during 1991 (Fig. 1), only protozoa from the $5 \mathrm{~m}$ samples were enumerated in 1992. Within the flagellate assemblage, cells $<20 \mu \mathrm{m}$ (primarily cells 5 to $15 \mu \mathrm{m}$ in length) were always numerically dominant and accounted for 50 (May) to $\geq 80 \%$ (June to September) of the protist assemblage (Fig 2a). They reached their highest concentrations during summer (Fig. 2b), when the bulk of the chl a biomass was $<5 \mu \mathrm{m}$ (Fig. 2e). Concentrations of nanoflagellates displayed a seasonal trend relatively similar to that of cyanobacteria (Fig. 2b) but not of chl $a<5 \mu \mathrm{m}$ (Fig. 2d). In 1992, the abundances of nanoflagellates varied throughout the summer, with high concentrations being abserved 3 times. The 3 peaks closely followed or corresponded to peak concentrations of cyanobacteria (Fig. 2b). Contribution of flagellates $>20 \mu \mathrm{m}$ to the protist assemblage was always $<30 \%$
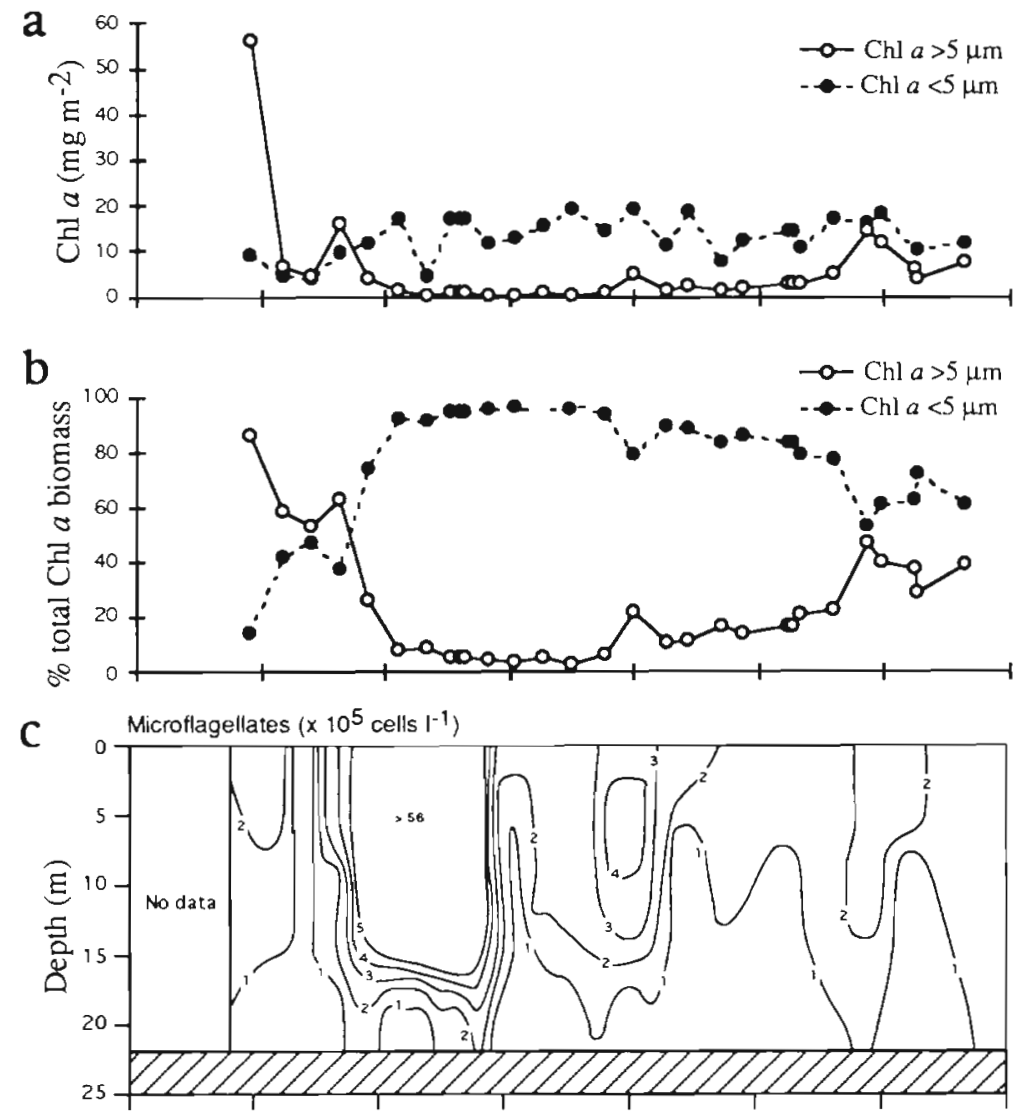

d
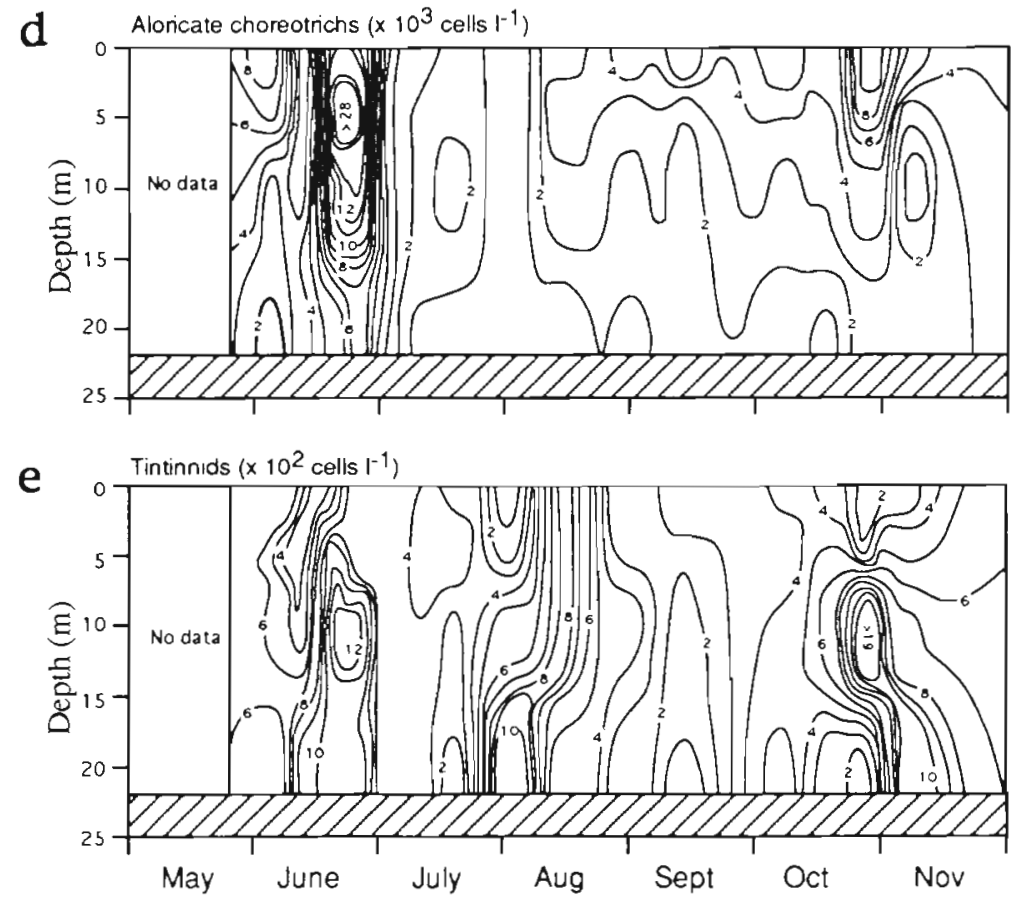

Fig. 1. Seasonal changes in 1991 in (a) chl a concentrations of phytoplankton $>5$ and $<5 \mu \mathrm{m}$, (b) relative contributions (\%) of the 2 size fractions to the total biomass of phytoplankton (values were integrated over the $22 \mathrm{~m}$ water column), and depths of isopleths for the concentrations of (c) microflagellates, (d) aloricate choreotrichs, and (e) tintinnids 

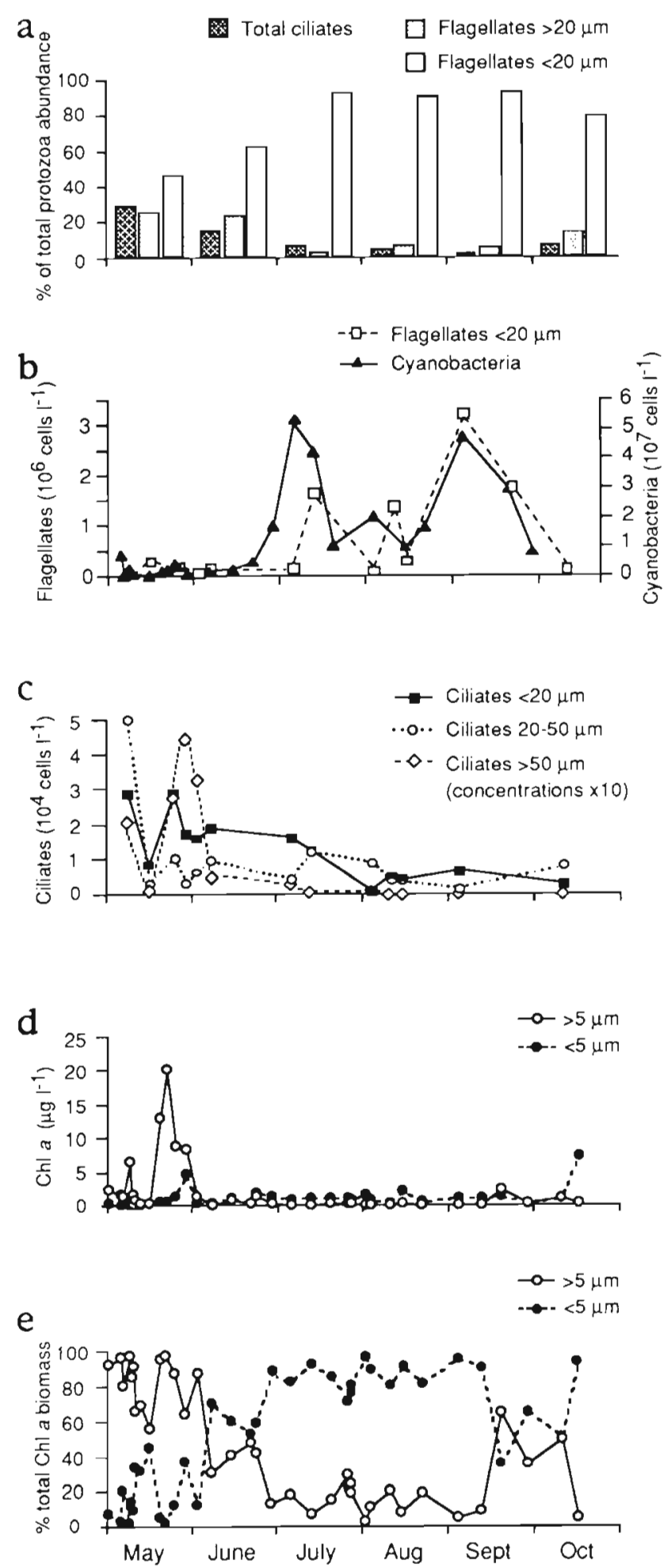

Fig. 2. Seasonal changes at $5 \mathrm{~m}$ depth in 1992 in (a) relative contributions $(\%)$ of ciliates and flagellates to total protist abundance, (b) concentrations of flagellates $<20 \mu \mathrm{m}$ and cyanobacteria, (c) concentrations of ciliates in 3 size fractions, (d) concentrations of chl $a$ in fractions $>5$ and $<5 \mu \mathrm{m}$, and (e) relative contributions ( $\%$ ) of the 2 size fractions to the total biomass of phytoplankton
(Fig. 2a). Flagellates $<20 \mu \mathrm{m}$ reached their highest concentrations during May and June, with values

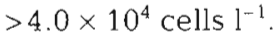

Within the ciliate assemblage, concentrations of cells tended to decrease from small $(<20 \mu \mathrm{m})$ to large (>50 $\mu \mathrm{m}$ ) organisms. The overall abundance of ciliates was highest during May and at the beginning of June (Fig. 2c), i.e. the period when the phytoplankton biomass was dominated by the $>5 \mu \mathrm{m}$ fraction (Fig. 2e). Following the spring diatom bloom, the abundance of ciliates remained at low level until October. Ciliates $>50 \mu \mathrm{m}$ were only observed from May through July and their concentrations were relatively low (Fig. 2c). During the spring, ciliates $>50 \mu \mathrm{m}$ accounted for up to $17 \%$ of the ciliate assemblage whereas, after June, their contribution was generally $<1 \%$. Ciliates $>50 \mu \mathrm{m}$ were primarily Laboea strobila, Helicostomella sp., and a large (60 to $80 \mu \mathrm{m}$ diam.) Strobilidium sp. With the exception of high values during the bloom of chain forming diatoms, in May, abundances of ciliates in the 20-50 $\mu \mathrm{m}$ size range remained at ca $5 \times 10^{3}$ cells $\mathrm{l}^{-1}$ during the whole sampling season (Fig. 2C), their contribution to the ciliate assemblage ranging from 29 to $59 \%$. As was the case for the other size fractions, the abundance of ciliates $<20 \mu \mathrm{m}$ was higher during spring than summer and, on the whole, they numerically dominated the ciliate assemblage.

\section{Carbon biomass of protozoa in 1992}

The total carbon biomass of protozoa reached its highest values during spring (>500 $\left.\mu \mathrm{g} \mathrm{C} \mathrm{l}^{-1}\right)$, after which there was a decrease to low values $k<100 \mu \mathrm{g} \mathrm{C}$ $\mathrm{l}^{-1}$ ) during summer and autumn (Fig 3a). During spring and at the beginning of summer, ciliates dominated the biomass of the protozoan assemblage; whereas, at the end of summer and in autumn, flagellates were the major contributors.

The biomass of the total ciliate assemblage (Fig. 3a) was highest during spring (>400 $\left.\mu \mathrm{g} \mathrm{C} \mathrm{l}^{-1}\right)$ and remained at lower values during summer and autumn $\left(<100 \mu \mathrm{g} \mathrm{C} \mathrm{l}^{-1}\right)$, this decline being observed for cells both $<20$ and $>20 \mu \mathrm{m}$ (not shown). In contrast to cell numbers, where the major contribution was that of ciliates $<20 \mu \mathrm{m}$ (Fig. 2c), ciliates $>20 \mu \mathrm{m}$ always dominated the biomass of the ciliate assemblage (Fig 3c). Ciliates 50 to $200 \mu \mathrm{m}$ were dominant during May and June, whereas cells $20-50 \mu \mathrm{m}$ dominated the ciliate biomass from July through October

Cells $>20 \mu \mathrm{m}$ (Fig. 3b) generally dominated the carbon biomass of flagellates, their proportion decreasing from May through October. In contrast, the contribution of flagellates $<20 \mu \mathrm{m}$ to the total flagellate biomass increased during summer, reaching $46 \mu \mathrm{g} \mathrm{Cl}^{-1}$ in Sep- 

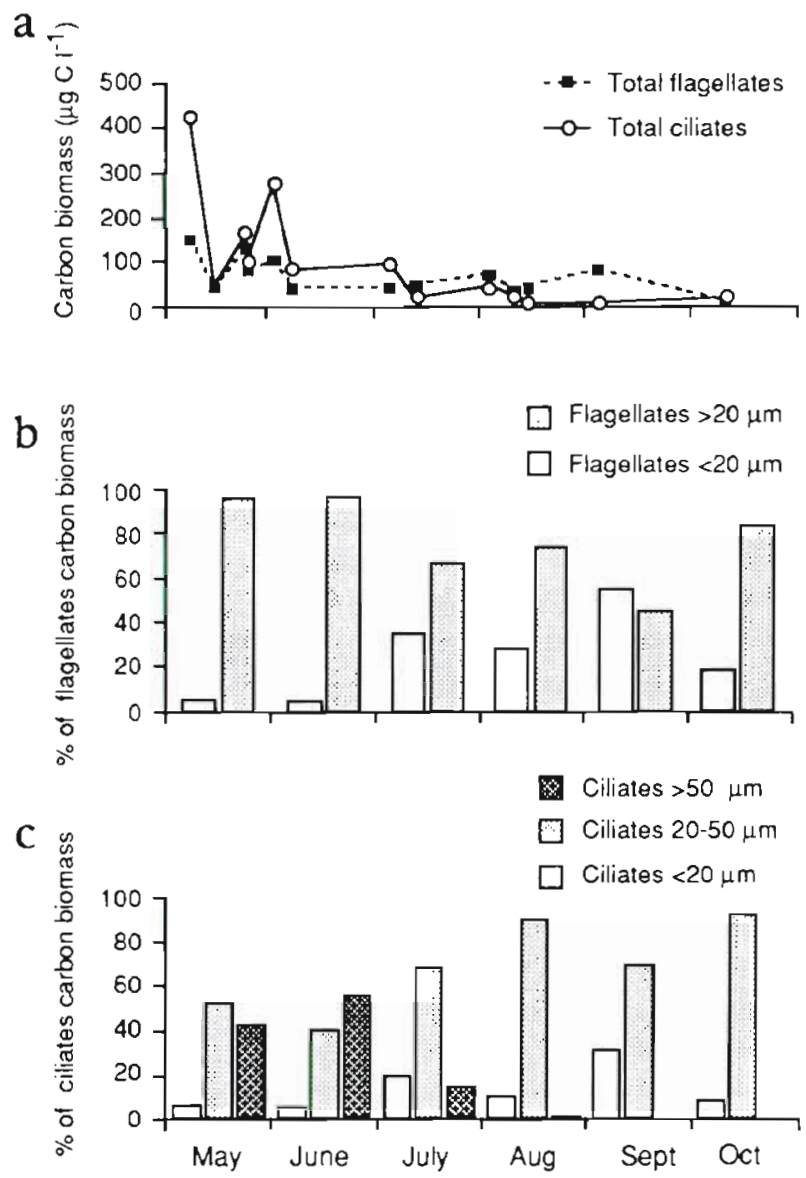

Fig. 3. Seasonal changes at $5 \mathrm{~m}$ depth in 1992 in (a) carbon biomass of the ciliate and flagellate assemblages, (b) relative contributions $(\%)$ of flagellates $>20$ and $<20 \mu \mathrm{m}$ to the flagellate biomass, and (c) relative contributions (\%) of ciliates $>20$, $20-50$ and $<20 \mu \mathrm{m}$ to the ciliate biomas

tember. Within the flagellates $>20 \mu \mathrm{m}$, there were some large naked and thecate dinoflagellates belonging to heterotrophic or mixotrophic genera. These represented high carbon biomasses, with standing stocks up to $270 \mu \mathrm{g} \mathrm{C} \mathrm{l}^{-1}$ during the spring diatom bloom in May (Fig. 4). At this time of the year, Gyrodinium spirale and Gymnodinium spp. were the most abundant dinoflagellates, with concentrations up to $1 \times 10^{4}$ and $3.5 \times 10^{4}$ cells $1^{-1}$, respectively. From June through October, the concentrations and carbon biomasses of heterotrophic dinoflagellates $>20 \mu \mathrm{m}$ steadily decreased to low values (Fig. 4).

\section{Trophic relationships between protists and phytoplankton size fractions}

In 1991, there were significant positive linear correlations between the abundances of both aloricate choreotrichs and tintinnids and chl $a$ in the $>5 \mu \mathrm{m}$ frac-
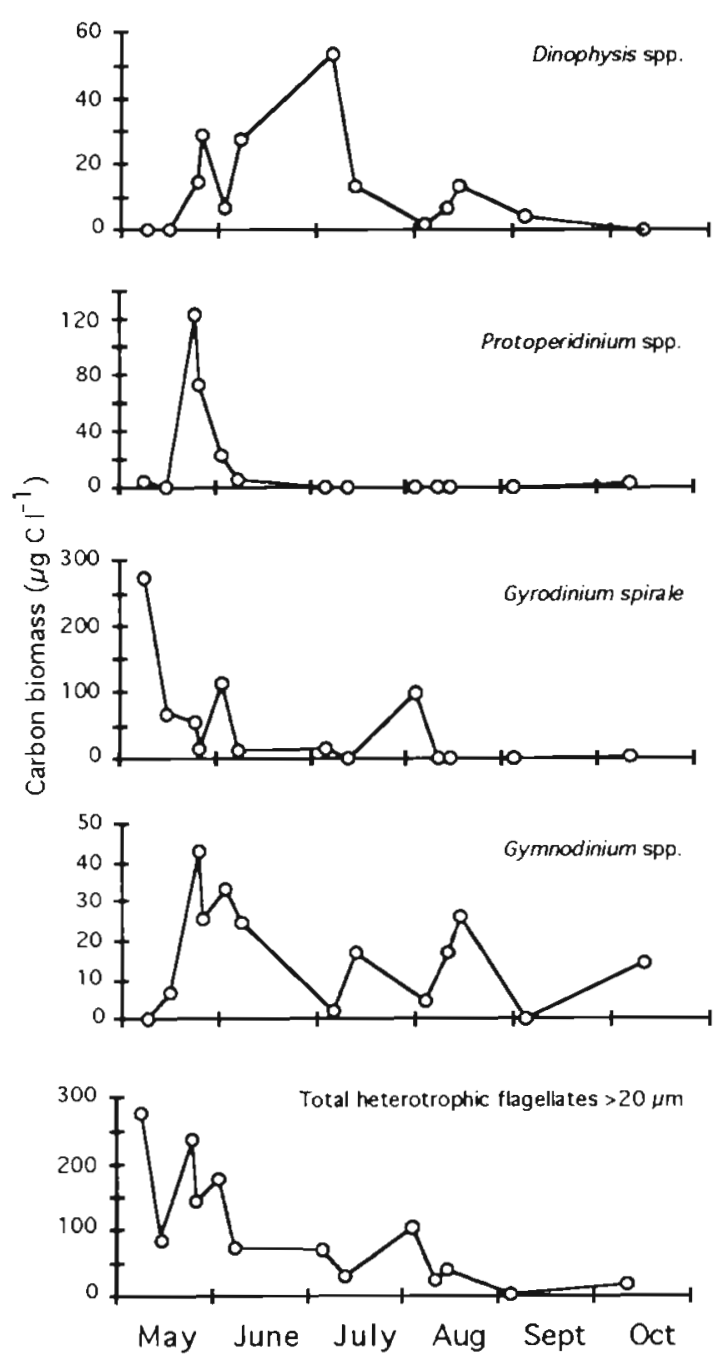

Fig. 4. Seasonal changes in carbon biomasses of heterotrophic dinoflagellates $>20 \mu \mathrm{m}$ at $5 \mathrm{~m}$ depth in 1992

tion (Table 1a). Correlations between microflagellate abundances and size-fractionated chl a were not statistically significant. Using data from 1992, correlations were computed between the abundance and biomass of each size fraction of ciliates and flagellates and the chl $a$ in 2 size fractions (Table $1 b$ ). Concentrations and biomasses of ciliates (except those $>50 \mu \mathrm{m}$ ) were significantly correlated with chl $a$ in the $>5 \mu \mathrm{m}$ fraction, but not with that in the $<5 \mu \mathrm{m}$ fraction. Biomass of flagellates $>20 \mu \mathrm{m}$ was also significantly correlated with $\mathrm{chl} a$ in the $>5 \mu \mathrm{m}$ fraction. Finally, the concentrations and biomasses of protists were not significantly correlated with the biomasses of single celled cyanobacteria (Table 1b).

Path analysis was used to further elucidate seasonal changes in the interactions among temperature, protist abundances, and the concentrations of their potential food particles. Fig. 5a shows the model of maximum 
Table 1 (a) Linear correlation coefficients between abundances of ciliates (aloricate choreotrichs and tintinnids) and flagellates and chl a biomass in 2 size fractions in 1991 ( $n=15$, values integrated over the $22 \mathrm{~m}$ water column). (b) Correlations betweeen the cell concentrations and carbon biomass of ciliates and flagellates and the size-fractionated chl a and carbon biomass of cyanobacteria in $1992(n=13) \cdot p<0.05$; ns: not significant ( $p>0.05)$; nm: not measured

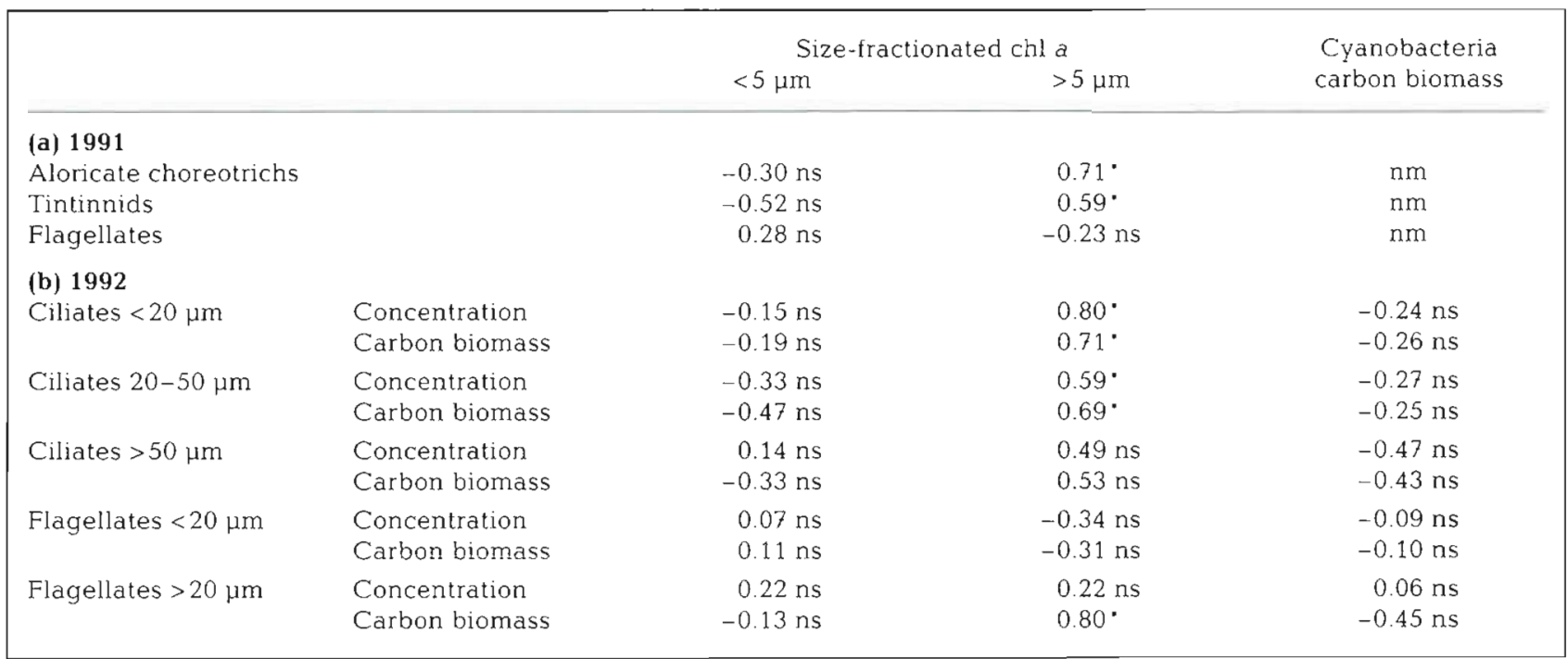

hypothesised causal interrelationships among variables. Separate calculations were done for the spring phytoplankton bloom (28 May to 24 June), summer (1 July to 20 August) and late summer-autumn (27 August to 15 November), using the large 1991 data set. Only statistically significant path coefficients $(p<0.05)$ are shown in Fig. 5b-d, where the percentage of noncausal relationships (spurious correlations) are also given.

Results from path analysis were different for the 3 seasons (Fig. $5 b-d$ ). Overall, relationships between protists and phytoplankton were stronger and more complex during the spring diatom bloom than during summer and autumn. In spring (Fig. 5b), the abundance of microflagellates was strongly and positively related to the concentration of chl $a<5 \mu \mathrm{m}$ (path coefficient $=0.74)$, whereas it was negatively related to chl $a>5 \mu m(-0.35)$. During spring, the highest path coefficient (1.02) was from chl $a<5 \mu \mathrm{m}$ to aloricate ciliates and the abundance of tintinnids was positively related to chl $a>5 \mu \mathrm{m}$ (0.88). In summer (Fig. $5 \mathrm{c}$ ), there was a positive path from chl $a<5 \mu \mathrm{m}$ to aloricate ciliates $(0.82)$ and to flagellates (0.93). In late summerautumn (Fig. 5d), there was a positive path from chl a $<5 \mu \mathrm{m}$ to flagellates $(0.57)$ and aloricate ciliates $(0.79)$. However, $67 \%$ of the path from chl $a<5 \mu \mathrm{m}$ to aloricate ciliates was non causal (spurious) There was no significant path from chl a $>5 \mu \mathrm{m}$ to protists.

The paths from temperature to protists were never significant during the sampled periods (Fig 5b-d). In contrast, there were strong and positive paths from temperature to chl $a<5 \mu \mathrm{m}$ during spring (0.86), sum- mer (0.70), and late summer-autumn (0.50). In summer, there was a significant path from temperature to chl a $>5 \mu \mathrm{m}(0.71)$.

\section{Grazing experiments in 1992}

Initial conditions for the grazing experiments are given in Table 2. Assemblages of protozooplankton $<64 \mu \mathrm{m}$ in the incubation bottles were always numerically dominated by flagellates $<20 \mu \mathrm{m}$ and, with 2 exceptions in May, ciliates $>50 \mu \mathrm{m}$ were virtually absent from the bottles during summer. Generally, the abundance of ciliates $<20 \mu \mathrm{m}$ was higher than or similar to that of ciliates $20-50 \mu \mathrm{m}$. Initial chl a concentrations in control bottles filled with the particle free seawater were $<0.05 \mu \mathrm{g} \mathrm{l}^{-1}$ and no increase occurred during the course of incubations.

Results from the 06 May, 23 May and 11 August incubations cannot be used, because the slopes $(g)$ of the regressions were not significantly different from zero (Table 3 ). For the remaining dates, growth rates of phytoplankton estimated from grazing experiments were high, i.e. values decreased from 1.58 doublings $\mathrm{d}^{-1}$ at the end of spring to 0.61 at the end of summer. During the incubations, protozoan grazers removed between 29 and $42 \%$ of the initial phytoplankton standing stock per day. Between 54 and $125 \%$ of phytoplankton potential production was grazed daily (Table 3). The grazing coefficients were relatively homogeneous throughout the sampling season, with values ca $0.5 \mathrm{~d}^{-1}$. 
a Maximum hypothesized causal relationships

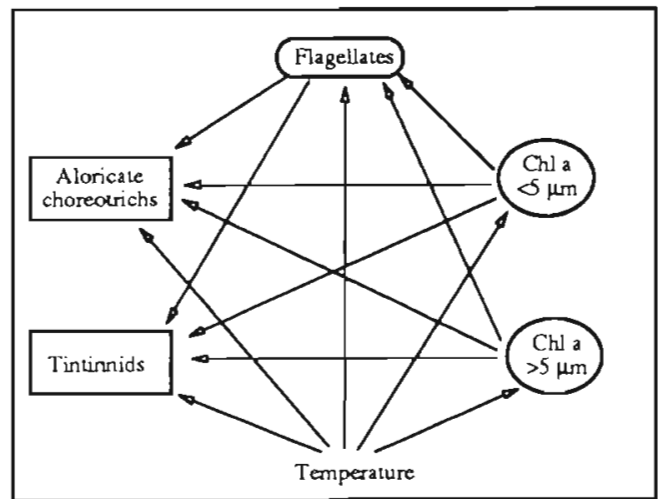

b

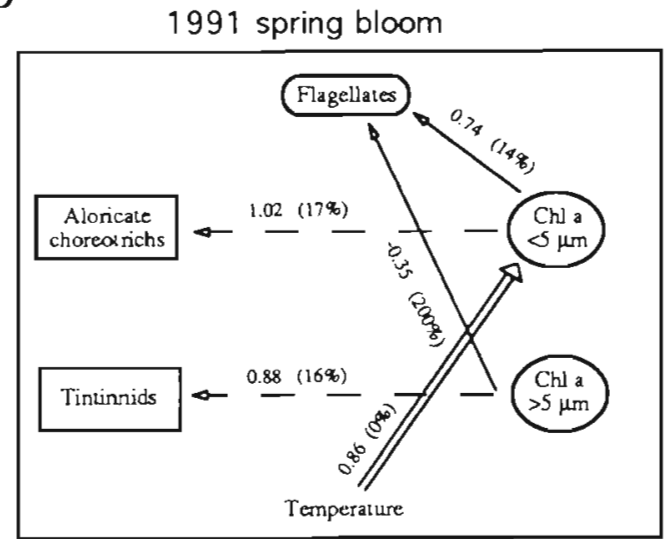

C

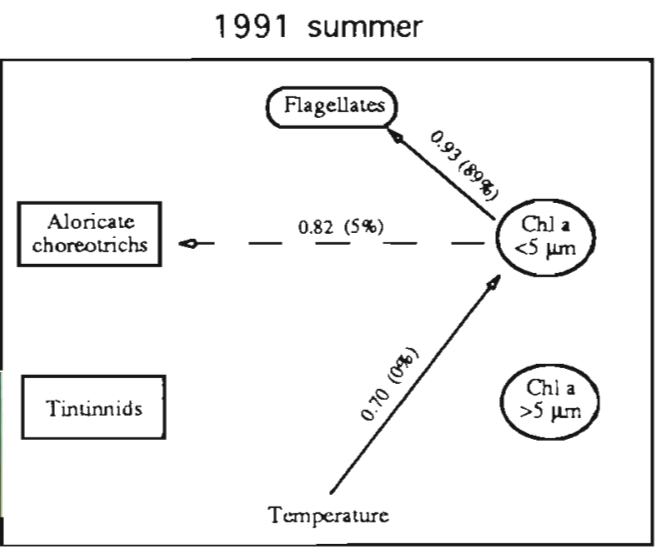

d

1991 late summer-autumn

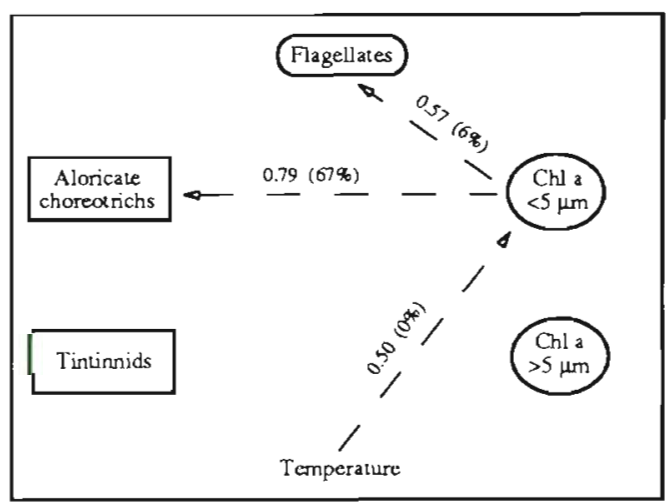

Fig. 5. Schematic representation of path analyses showing (a) the model of maximum hypothesized causal relationships among temperature, protists, and phytoplankton and the path coefficients computed using 1991 data from the (b) spring bloom, (c) summer, and (d) late summer-autumn. ( $\Rightarrow$ ) $p<0.001 ;(\Longrightarrow 0.001<p<0.01 ;(-\infty) 0.01<p<0.05$. Only significant $(p<0.05)$ path coefficients are shown. The intensity of the path and the percentage of non-causal relationship (spurious correlation) are given

Since flagellates and ciliates $<20 \mu \mathrm{m}$ are considered to be bacterivorous, and therefore should not significantly graze phytoplankton, the average clearance rates of protists were calculated by dividing the daily loss of phytoplankton biomass in the incubation bottle by the corresponding abundance of protists $>20 \mu \mathrm{m}$. Clearance rates estimated for protists $>20 \mu \mathrm{m}$ were between 0.4 and $8 \mu l$ ind. ${ }^{-1} \mathrm{~h}^{-1}$, so that, on average, the phytoplankton carbon grazed by these protists was $11 \mu \mathrm{g} \mathrm{Cl}^{-1} \mathrm{~d}^{-1}$ (Table 4). Phytoplankton growth rates

Table 2. Conditions in undiluted controls at the start of grazing expenments and ambient seawater temperature recorded at $5 \mathrm{~m}$ depth before the incubations started

\begin{tabular}{|c|c|c|c|c|c|c|c|c|}
\hline \multirow{2}{*}{$\begin{array}{l}\text { Date } \\
(1992)\end{array}$} & \multirow{2}{*}{$\begin{array}{c}\text { Ambient } \\
\text { temperature } \\
\left({ }^{\circ} \mathrm{C}\right)\end{array}$} & \multirow{2}{*}{$\begin{array}{c}\text { Initial algal } \\
\text { biomass } \\
\left(\mu g \text { chl a l }{ }^{-1}\right)\end{array}$} & \multirow{2}{*}{$\begin{array}{c}\text { Initial ciliate } \\
\text { biomass } \\
\left(\mu \mathrm{g} \mathrm{Cl}^{-1}\right)\end{array}$} & \multicolumn{3}{|c|}{ Choreotrich ciliates } & \multicolumn{2}{|c|}{ Flagellates } \\
\hline & & & & $\begin{array}{c}<20 \mu \mathrm{m} \\
\left(\text { cells } 1^{-1} \text { ) }\right.\end{array}$ & $\begin{array}{l}20-50 \mu \mathrm{m} \\
\text { (cells })^{-1} \text { ) }\end{array}$ & $\begin{array}{l}>50 \mu \mathrm{m} \\
\text { (cells } 1^{-1} \text { ) }\end{array}$ & $\begin{array}{l}<20 \mu \mathrm{m} \\
\left(\text { cells } \mathrm{I}^{-1} \text { ) }\right.\end{array}$ & $\begin{array}{c}>20 \mu \mathrm{m} \\
\text { (cells } 1^{-i} \text { ) }\end{array}$ \\
\hline 6 May & 1.5 & 2.85 & 130 & $2.6 \times 10^{4}$ & $1.7 \times 10^{4}$ & $1.4 \times 10^{3}$ & $2.2 \times 10^{3}$ & $2.8 \times 10^{3}$ \\
\hline 23 May & 6.5 & 2.76 & 112 & $2.8 \times 10^{4}$ & $1.0 \times 10^{4}$ & $2.4 \times 10^{3}$ & $1.6 \times 10^{5}$ & $49 \times 10^{4}$ \\
\hline 31 May & 7.8 & 0.45 & 263 & $1.6 \times 10^{4}$ & $5.6 \times 10^{3}$ & $<10^{2}$ & $7.3 \times 10^{4}$ & $34 \times 10^{4}$ \\
\hline $29 \mathrm{Jul}$ & 14.7 & 2.05 & 17 & $5.2 \times 10^{3}$ & $2.0 \times 10^{3}$ & $<10^{2}$ & $4.7 \times 10^{5}$ & $3.8 \times 10^{3}$ \\
\hline 7 Aug & 12.3 & 0.35 & 24 & $5.4 \times 10^{3}$ & $3.7 \times 10^{3}$ & $<10^{2}$ & $1.4 \times 10^{6}$ & $1.8 \times 10^{4}$ \\
\hline 11 Aug & 12.6 & 1.62 & 16 & $4.5 \times 10^{3}$ & $4.2 \times 10^{3}$ & $<10^{2}$ & $3.0 \times 10^{5}$ & $2.5 \times 10^{4}$ \\
\hline $13 \mathrm{Aug}$ & 11.0 & 0.53 & 8 & $2.1 \times 10^{3}$ & $2.1 \times 10^{3}$ & $<10^{2}$ & $1.6 \times 10^{5}$ & $<10^{2}$ \\
\hline
\end{tabular}


Table 3. Grazing of phytoplankton chl a by protozooplankton: results of dilution experiments. $k$ : phytoplankton growth coefficient; $g$ : grazing coefficient; phytoplankton doublings $=k / \ln 2$; potential phytoplankton production $=\left(P_{0} \mathrm{e}^{k}\right)-P_{0}$; actual phytoplankton production $=\left(P_{0} \mathrm{e}^{|k-g|}\right)-P_{0} ; \%$ initial chl a removed $=($ potential production - actual production $) / P_{0 i} \%$ potential production removed $=($ potential production - actual production $) /$ potential production; $" \mathrm{p}<0.05$; ns: not significant $(p>0.05)$

\begin{tabular}{|c|c|c|c|c|c|c|}
\hline $\begin{array}{l}\text { Date } \\
\text { (1992) }\end{array}$ & $\begin{array}{c}k \\
\left(\mathrm{~d}^{-1}\right)\end{array}$ & $\begin{array}{l}\text { Phytoplankton } \\
\text { doublings } \\
\left(\mathrm{d}^{-1}\right)\end{array}$ & $\begin{array}{l}\% \text { initial chl a } \\
\text { produced } \\
\quad\left(\mathrm{d}^{-1}\right)\end{array}$ & $\underset{\left(d^{-1}\right)}{g}$ & $\begin{array}{l}\% \text { initial chl } a \\
\text { removed } \\
\left(\mathrm{d}^{-1}\right)\end{array}$ & $\begin{array}{l}\% \text { potential phytoplankton } \\
\text { production removed } \\
\qquad\left(\mathrm{d}^{-1}\right)\end{array}$ \\
\hline 6 May & ns & ns & ns & ns & ns & $\mathrm{ns}$ \\
\hline 23 Мay & ns & ns & ns & ns & ns & ns \\
\hline 31 May & $1.09^{\circ}$ & 1.58 & 198 & $0.54^{\circ}$ & 42 & 63 \\
\hline $29 \mathrm{Jul}$ & $0.77^{\circ}$ & 1.11 & 115 & $0.34^{\circ}$ & 29 & 54 \\
\hline 7 Aug & $0.65^{\circ}$ & 0.94 & 92 & $0.40^{\circ}$ & 33 & 69 \\
\hline 11 Aug & ns & ns & ns & ns & ns & ns \\
\hline 13 Aug & $0.41^{\circ}$ & 0.61 & 51 & $0.55^{\circ}$ & 42 & 125 \\
\hline
\end{tabular}

Table 4. Estimated clearance rate of protists $>20 \mu \mathrm{m}$ and phytoplankton carbon grazed daily. Estumated hourly clearance rate $=\left(\right.$ incubated water cleared $\left.\mathrm{d}^{-1}\right) /(24 \mathrm{~h} \times$ protist concentration); incubated water cleared $\mathrm{d}^{-1}=\% P_{0}$ grazed $\mathrm{d}^{-1}$ phytoplankton carbon grazed $=\% P_{0}$ grazed $\mathrm{d}^{-1} \times P_{0} \times 40 \mu \mathrm{g}$ $\mathrm{C}^{-1} \mu \mathrm{g}$ chl a

\begin{tabular}{|lcc}
\hline $\begin{array}{l}\text { Date } \\
(1992)\end{array}$ & $\begin{array}{c}\text { Clearance rate } \\
\left(\mu \text { ind }^{-1} \mathrm{~h}^{-1}\right)\end{array}$ & $\begin{array}{c}\text { Carbon grazed } \\
\left(\mu \mathrm{g} \mathrm{C} \mathrm{d}^{-1}\right)\end{array}$ \\
\hline 31 May & 0.41 & 8 \\
$29 \mathrm{Jul}$ & 2.07 & 24 \\
7 Aug & 0.63 & 5 \\
13 Aug & 7.88 & 9 \\
\hline
\end{tabular}

computed using results from the ${ }^{14} \mathrm{C}$ primary production experiments were between 0.4 and 1.5 doublings $\mathrm{d}^{-1}$, whereas growth rates estimated from the results of dilution experiments were between 0.9 and 1.6 doublings $\mathrm{d}^{-1}$.

\section{DISCUSSION}

\section{Methodological considerations}

Before discussing the results, potential bias of the serial dilution method must be addressed. For example, nutrient recycling may be low in the most dilute treatments, so that nutrient limitation may affect phytoplankton growth. In the present study, macronutrient concentrations in all incubation bottles were always above detection at the end of the incubation. Furthermore, the fact that growth rates of phytoplankton in the incubation experiments (Table 3) were relatively high and typical of temperate waters (see Goldman et al. 1979 for comparison) indicates that no nutrient limitation occurred during the course of the incubations.
Changes in assemblages may occur at the prefiltration step (Lynn \& Montagnes 1991). The effect of reverse filtration with a $64 \mu \mathrm{m}$ mesh on the ciliate assemblage was examined and no significant decrease or change was found, i.e. ciliate concentrations in the undiluted bottles were always within the range of concentrations observed during the seasonal survey (Figs. 1 \& 2). Finally, since phytoplankton never reached high biomasses in the experiments, the plots of apparent growth rate versus fraction of undiluted seawater never exhibited non-linearity, which would have been indicative of saturated feeding responses.

\section{Protozooplankton abundance and biomass}

Concentrations of protozooplankton in the present study (Figs. $1 \& 2$ ) are similar to those generally reported for temperate nearshore and estuarine waters. Concentrations of flagellates as high as $10^{6}$ cells $l^{-1}$ are not exceptional in nearshore areas and in the open ocean (Painting et al. 1992, Vaqué et al. 1992). Values of $10^{3}$ to $10^{4}$ cells $\mathrm{l}^{-1}$ for aloricate choreotrichs and $<10^{2}$ to $10^{3}$ cells $\mathrm{l}^{-1}$ for tintinnids are generally observed in nearshore waters (Dolan \& Coats 1990, Pierce \& Turner 1992, Buskey 1993).

In contrast to cell concentrations, estimates of carbon biomasses for protozooplankton (Figs. $3 \& 4$ ) are quite high when compared with values from the literature. Biomasses of heterotrophic flagellates generally range between <0.1 and $50 \mu \mathrm{g} \mathrm{Cl}^{-1}$ (Lessard 1991). However, biomasses of heterotrophic flagellates $>100 \mu \mathrm{g} \mathrm{C} \mathrm{l}^{-1}$ have sometimes been reported in temperate nearshore waters during diatom blooms (Hansen 1991, Bralewska \& Witek 1995). Flagellate biomasses $>100 \mu \mathrm{g} \mathrm{C} \mathrm{l}^{-1}$ observed in May (Figs. $3 \& 4$ ) are therefore among the highest reported and can be attributed to the high abundances of large heterotrophic dinoflagellates like Gyrodinium spirale (Fig. 4), whereas the values from 
summer and autumn are less unusual. During summer and autumn, carbon biomasses of the ciliate assemblage were similar to those in other nearshore and estuarine systems. For example, ciliate biomasses of 8 to $16 \mu \mathrm{g} \mathrm{C} \mathrm{I}^{-1}$ were reported in Chesapeake Bay, USA (Dolan \& Coats 1990), 1 to $56 \mu \mathrm{g} \mathrm{C} \mathrm{l}^{-1}$ in Kiel Bight, Germany (Smetacek 1981), and 0.2 to $52 \mu \mathrm{g} \mathrm{Cl}^{-1}$ in the St. Lawrence Estuary (Sime-Ngando et al. 1995). Values $>150 \mu \mathrm{g} \mathrm{Cl}^{-1}$ observed during May and June are unusual and related to the high concentrations of large ciliates such as tintinnids.

\section{Size structure of phytoplankton and protozooplankton and controlling factors}

The concentration and biomass of protozooplankton generally followed the seasonal dynamics of phytoplankton. Peaks in protozooplankton abundance and biomass precisely matched the spring and autumn blooms of phytoplankton $>5 \mu \mathrm{m}$, whereas abundances and biomasses of protozoa decreased during summer, when phytoplankton were dominated by the $<5 \mu \mathrm{m}$ fraction (Figs. 1 to 4 ). The high correlation coefficients between the biomasses of protozooplankton and phytoplankton $>5 \mu \mathrm{m}$ (Table 1) may be an indication that the 2 variables responded similarly to the same environmental factor (e.g. temperature), or that dynamics of protozooplankton, on the whole, responded to the abundance of large phytoplankton, or that the 2 were controlled by mesozooplankton grazing. These 3 alternatives are, in turn, discussed here.

(1) The possibility that correlations between the 2 groups reflected the influence of temperature was tested using partial correlations. When controlling for the effect of temperature in 1991, the abundances of aloricate choreotrichs and tintinnids remained significantly correlated to chl $a>5 \mu \mathrm{m}(\mathrm{r}=0.82, \mathrm{p}<0.01$ and $\mathrm{r}=0.63, \mathrm{p}<0.05$, respectively). In 1992, the only partial correlation significantly different from zero was that between ciliates $<20 \mu \mathrm{m}$ and chl $a>5 \mu \mathrm{m}$ ( $\mathrm{r}=0.74$, $p<0.01$ ). Accordingly, path analysis showed no significant causal relationship between temperature and protist abundance or chl a $>5 \mu \mathrm{m}$ in 1991 (Fig. 5). Thus, temperature changes alone cannot completely explain the parallel variations of large phytoplankton and protozooplankton, which were observed during the 2 sampling seasons.

(2) In nearshore waters of the Kattegat, heterotrophic dinoflagellates $>20 \mu \mathrm{m}$ are abundant during periods dominated by large phytoplankton, upon which they feed (e.g. spring diatom bloom and autumn bloom of autotrophic dinoflagellates), whereas smaller forms are abundant during periods dominated by nanophytoplankton (Hansen 1991). Similarly, in the Baie des
Chaleurs, heterotrophic dinoflagellates, like Dinophysis spp., Protoperidinium spp., Gyrodinium spp., and Gymnodinium spp., which are grazers of large diatoms (Jacobson \& Anderson 1986, Hansen 1991, Neuer \& Cowles 1994), were particularly abundant during the spring diatom bloom (Fig. 4). Given that feeding rates of dinoflagellates are comparable to those of ciliates (Capriulo 1991), large flagellates can sometimes be major grazers of diatom blooms (Lessard 1991). Consequently, high concentrations and biomasses of large herbivorous flagellates in the bay during spring may have been related to the high biomasses of their food items, i.e. diatoms. This is supported by the strong correlation between the carbon biomass of flagellates $>20 \mu \mathrm{m}$ and chl a $>5 \mu \mathrm{m}$ in 1992 (Table 1). However, since large flagellates and the dominating nanoflagellates were not enumerated separately in 1991, path analysis did not show any significant link between large phytoplankton and large flagellates during the spring bloom (Fig. 5b). These results stress the potential importance of large flagellates in the fate of the spring phytoplankton bloom in the nearshore waters of the Baie des Chaleurs.

A trophic relationship between ciliates and phytoplankton $>5 \mu \mathrm{m}$ (Table 1, Fig. $5 \mathrm{~b}$ ), the latter being primarily chain-forming diatoms of the spring bloom, would be more unusual, since laboratory experiments have shown that naked oligotrichous ciliates and tintinnids feed almost exclusively on nanoplankton (Rassoulzadegan et al. 1988, Bernard \& Rassoulzadegan 1990). However, in the Baie des Chaleurs, ciliates did respond numerically to the spring phytoplankton bloom in both 1991 and 1992 (Figs. 1 \& 2). The sizes of individual cells of the chain-forming bloom diatoms (primarily Chaetoceros spp. and Thalassiosira spp.) were $<30 \mu \mathrm{m}$, i.e. in the size range potentially available to ciliates. Results from a study in the northwest Atlantic support the view that ciliates can efficiently feed on chain-forming diatoms and control their growth (Paranjape 1990). In addition, in the St. Lawrence Estuary, microscopic observations showed ciliates with up to 10 ingested cells of bloom forming diatoms such as Skeletonema spp., Chaetoceros spp. and Thalassiosira spp. (Sime-Ngando et al. 1995). Given that high abundance and biomass of ciliates were observed during the spring and the ciliates and diatoms were similar to those observed by SimeNgando et al. (1995), it is concluded that herbivorous ciliates likely played an important role as consumers of the spring diatom bloom in the nearshore waters of the Baie des Chaleurs.

The carbon standing stock of heterotrophic ciliates varied from 10 to $530 \%$ of that of phytoplankton (these values can be derived from Figs. $2 d \& 3 a$ ). Values well above $100 \%$ during spring and at the begin- 
ning of summer could only be supported by rapid phytoplankton growth. Maximum doubling rates of phytoplankton during spring were $>1 \mathrm{~d}^{-1}$ (Table 3 ), so that the high production of phytoplankton could support the high biomass of the ciliate assemblage dominated by large forms. During summer, the standing stock of heterotrophic ciliates was $<100 \%$ of the phytoplankton standing stock. In addition, nanoflagellates and ultraplanktonic eucaryotes were abundant, and their sizes ( 3 to $20 \mu \mathrm{m}$ ) were within the optimal range for tintinnids and aloricate ciliates $>50 \mu \mathrm{m}$ (Rassoulzadegan et al. 1988). Therefore, the relative disappearance of tintinnids and aloricate ciliates $>50 \mu \mathrm{m}$ during summer was probably not the result of food limitation. A recent study by Wiackowski et al. (1994) showed that, when total ciliate abundance is depressed by zooplankton, the relative frequency of larger ciliates decreases. Selective feeding by mesozooplankton on large heterotrophic flagellates has also been reported in a study by Weisse (1991). Thus, increased grazing by mesozooplankton on protozoa may have accounted for the shift from larger to smaller forms of ciliates and flagellates.

(3) A caveat to the above discussion on factors that possibly controlled the biomass and size structure of protozooplankton is the absence, in the present study, of data on the grazing of mesozooplankton on the protozoan assemblage. In 1991 and 1992, ratios of Phaeo/ (chl $a+$ Phaeo) in the $>20 \mu \mathrm{m}$ fraction (not shown), which can be considered a rough index of faecal pellet concentrations and mesozooplankton grazing (Welschmeyer et al. 1984, Bustillos-Guzman et al. 1996), provide indication that production of faecal pellets by mesozooplankton was higher during summer than spring. Seasonal changes in these ratios are consistent with published data on seasonal variations of mesozooplankton abundance in the Baie des Chaleurs (Fig. 6) (Lacroix \& Filteau 1970, 1971). Moreover, Y. Lagadeuc, M. Boulé \& J. Dodson (unpubl.) report that, at a nearshore station close to our sampling site, copepods reached particularly high concentrations in August and September 1991, with adults and nauplii often exceeding $2 \times 10^{4}$ ind. $\mathrm{m}^{-3}$ and Oithona similis and Pseudocalanus sp. dominating the copepod assemblage. These results are in agreement with qualitative samples taken at our station in July and August 1992, which showed that Oithona similis accounted for $44 \pm 21 \%$ of adult copepods and $53 \pm 22 \%$ of copepodites (not shown). Oithonidae are considered to be omnivorous, with a preference for motile food such as dinoflagellates (Paffenhöfer 1993)
Since (1) in temperate nearshore water, a greater percentage of the carbon ingested by copepods is generally supplied by ciliates when phytoplankton stocks are low or dominated by small cells (Fessenden \& Cowles 1994), as was the case in the present study from June until August (Figs. 1a \& 2d), (2) there are indications that concentrations and grazing activities of copepods reached their highest values during summer, and (3) small omnivorous Oithonidae dominated the copepod assemblage, we hypothesise that copepods exerted stronger grazing pressure on protozooplankton during summer than spring. The same was observed in the adjacent Gulf of St. Lawrence, where heterotrophic ciliates and dinoflagellates make up a high fraction of the diet of Calanus finmarchicus during summer, despite the low concentrations of these protists (Ohman \& Runge 1994). Similar changes in the seasonal dynamics of copepods were also proposed by Hansen (1991) to explain the peak of large heterotrophic dinoflagellates during the spring phytoplankton bloom and their absence during a late summer bloom, in nearshore waters of the Kattegat.

\section{Grazing effect of protozooplankton on phytoplankton}

Concentrations of single celled cyanobacteria in nearshore waters of the Baie des Chaleurs were high during summer (Fig. 2b). It is generally considered that nanoflagellates (Campbell \& Carpenter 1986) and ciliates $<20 \mu \mathrm{m}$ (Rassoulzadegan et al. 1988) are the main grazers of these autotrophic procaryotes. However, since the carbon biomass of cyanobacteria is low compared to that of autotrophic eucaryotes (Li 1995, Tamigneaux et al. 1995) and the efficiency of chl a extraction from cyanobacteria is low (Joint \& Pomeroy 1986), changes of chl a concentration in dilution experiments most probably reflect changes in the abundance of autotrophic nanoflagellates and dinofla-

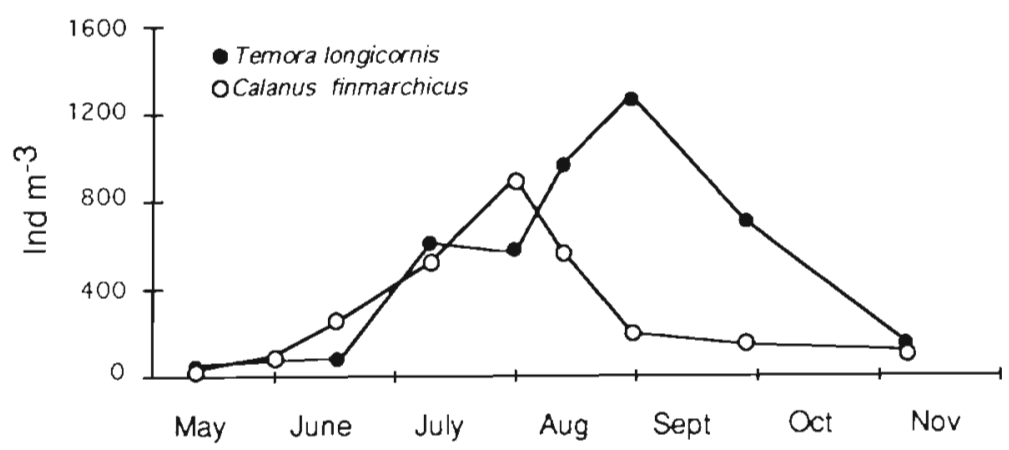

Fig. 6. Seasonal changes in the concentrations of 2 frequent and abundant copepod species in the 0 to $40 \mathrm{~m}$ layer of the Baie des Chaleurs (redrawn after Lacroix \& Filteau 1970, 1971) 
gellates and of diatoms instead of changes in the abundance of cyanobacteria. Consequently, grazing coefficients calculated from dilution experiments are considered to mainly reflect grazing by herbivorous ciliates and flagellates $>20 \mu \mathrm{m}$ on autotrophic eucaryotes. Clearance rates estimated for the assemblage of protozooplankton $>20 \mu \mathrm{m}$ were between 0.4 and $8 \mu \mathrm{l}$ ind.$^{-1} \mathrm{~h}^{-1}$ (Table 4 ). These estimates are at the lower end of values generally reported for tintinnids (up to $85 \mu \mathrm{l}$ ind. ${ }^{-1} \mathrm{~h}^{-1}$; Capriulo 1991), but within the range of clearance rates reported for ciliates $<50 \mu \mathrm{m}$, 0.36 to $6.38 \mu$ ind. $^{-1} \mathrm{~h}^{-1}$ (Bernard \& Rassoulzadegan 1990), for aloricate ciliates, 0 to $12 \mu$ ind. $^{-1} \mathrm{~h}^{-1}$ (Rublee \& Gallegos 1989), and for dinoflagellates, 0.5 to $28 \mu \mathrm{l}$ ind.$^{-1} \mathrm{~h}^{-1}$ (Lessard \& Swift 1985). This supports the idea that aloricate ciliates and flagellates $>20 \mu \mathrm{m}$, which were abundant in our experiments, played an important role as consumers of phytoplankton in nearshore waters.

There are few reports of grazing experiments that concern protozooplankton only, since most studies also included microzooplankton. In such experiments, small metazoa are allowed to compete with and/or prey on protozoan grazers. Our results are in agreement with those of a comparable study by Gifford (1988) in nearshore waters off Nova Scotia, for which water had been filtered through a $100 \mu \mathrm{m}$ mesh to remove copepod nauplii. It was found that 21 to $50 \%$ of the initial standing stock and 40 to $100 \%$ of the potential production were grazed daily by protozoa (in the Baie des Chaleurs, corresponding values were 29 to $42 \%$ and 54 to $125 \%$, respectively; Table 3 ). More generally, grazing rates in the present study were in the upper range of values reported for microzooplankton grazing (Pierce \& Turner 1992), indicating that, when predation is reduced, protozooplankton are able to consume all the primary production and even more. Indeed, in spite of relatively high primary production (Table 5), chl a biomass remained low and relatively stable during the summer months (Figs. 1a \& 2d). However, since water in experiments was prefiltered

Table 5. Comparison of phytoplankton growth rates estimated from the results of in situ grazing experiments and from in situ incubations using the ${ }^{14} \mathrm{C}$ primary production method. ${ }^{14} \mathrm{C}$ doublings per day = primary production/(chl $\left.a \times 30 \mu \mathrm{g} \mathrm{C} \mu \mathrm{g} \mathrm{chl} a^{-1}\right)$. ns: not significant $(\mathrm{p}>0.05)$

\begin{tabular}{|ccccc|}
\hline $\begin{array}{l}\text { Date } \\
(1992)\end{array}$ & $\begin{array}{c}\text { Phytoplankton } \\
\text { chl a biomass } \\
\left(\mu \mathrm{g} \mathrm{chl} \mathrm{a}^{-1}\right)\end{array}$ & $\begin{array}{c}{ }^{14} \mathrm{C} \text { primary } \\
\text { production } \\
\left(\mu \mathrm{C} \mathrm{C}^{-1} \mathrm{~d}^{-1}\right)\end{array}$ & $\begin{array}{c}{ }^{14} \mathrm{C} \text { doublings } \\
\mathrm{d}^{-1}\end{array}$ & $\begin{array}{c}\text { Grazing expt } \\
\text { doublings } \\
\mathrm{d}^{-1}\end{array}$ \\
\hline $6 \mathrm{May}$ & 2.85 & 37 & 0.43 & $\mathrm{~ns}$ \\
$23 \mathrm{May}$ & 2.80 & 116 & 1.38 & $\mathrm{~ns}$ \\
31 May & 1.53 & 52 & 1.13 & 1.58 \\
29 Jul & 1.78 & 23 & 0.4 & 1.11 \\
$7 \mathrm{Aug}$ & 0.40 & 18 & 1.5 & 0.94 \\
\hline
\end{tabular}

through a $64 \mu \mathrm{m}$ mesh, chain-forming diatoms may have been fragmented into smaller components, thus making some additional phytoplankton biomass available to ciliates. Grazing rates from May were therefore possibly overestimated. Keeping in mind these caveats, grazing by herbivorous ciliates and flagellates could account for the low and steady chl a biomass observed during summer.

\section{Estimated effect of grazing on cyanobacteria}

Maximum numbers of nanoflagellates were observed from the end of the spring bloom to the end of summer (Figs. $1 \& 2$ ) as is generally the case in temperate estuaries (Coffin \& Sharp 1987, Dolan \& Coats 1990). In contrast to nanoflagellates, ciliates $<20 \mu \mathrm{m}$ were more abundant from May to July than at the end of summer (Fig. 2c). However, because of the low contribution of large forms during summer, the relative contribution of the $<20 \mu \mathrm{m}$ fraction to the carbon biomass of ciliates was highest from July to September (Fig 3c). Nanoflagellates and ciliates $<20 \mu \mathrm{m}$ are considered to be consumers of ultraplanktonic and bacteria-sized particles (Reid et al. 1991), and, indeed, maximum concentrations of autotrophic ultraplankton $<5 \mu \mathrm{m}$ (i.e. cyanobacteria and eucaryotes) were observed from July through September (Figs. 1a \& 2b, d). That the biomass of phytoplankton $<5 \mu \mathrm{m}$ remained very constant during summer suggests a close coupling with their consumers.

To estimate the potential grazing of nanoflagellates on cyanobacteria, a clearance rate of $15 \mathrm{nl}$ ind.-1 $\mathrm{h}^{-1}$ was assumed for nanoflagellates grazing on these bacteria-sized algae (Caron et al. 1991). Because we could not reliably distinguish autotrophic from heterotrophic/mixotrophic protists, we made the conservative assumption that only $50 \%$ of the nanoflagellates were potential grazers of cyanobacteria. This is highly conservative since, in the Gulf of St. Lawrence, epifluorescence microscopy showed that mixotrophs may sometimes account for $94 \%$ of the flagellate assemblage, the remainder being heterotrophs (C. Lovejoy pers. comm.). Using the carbon biomass of cyanobacteria, it was calculated that flagellates $<20 \mu \mathrm{m}$ could consume 2 to $24 \%$ (mean = $6 \%$ ) of the standing stock of cyanobacteria. These results lead to the conclusion that the effect of nanoflagellates on cyanobacteria was probably weak. However, recent studies indicate that, in nearshore waters, ingestion rates of bacteria-sized food items by pigmented nanoflagellates are similar to those of 
nanoflagellates that lack chloroplasts (Epstein \& Shiaris 1992, Hall et al. 1993). In the present study, if all nanoflagellates were considered to be bacterivorous, they could play an important role in regulating cyanobacterial numbers but they would probably not fully control them.

Small ciliates are the next candidates as grazers of cyanobacteria, since it has been reported that picoplankton may constitute up to $72 \%$ of the diet of ciliates $<30 \mu \mathrm{m}$ (Rassoulzadegan et al. 1988) and individual clearance rates of ciliates are higher than those of nanoflagellates. In addition, small oligotrichs may have significantly higher clearance rates for cyanobacteria compared to those for bacteria, these ciliates meeting all of their carbon requirements by feeding exclusively on picoplankton (Simek et al. 1996). Assuming a clearance rate of $0.5 \mu \mathrm{l}$ ind.$^{-1} \mathrm{~h}^{-1}$ for ciliates $<20 \mu \mathrm{m}$ grazing on cyanobacteria (Bernard \& Rassoulzadegan 1990), it is estimated that these small ciliates could have consumed an average $0.41 \mu \mathrm{g} \mathrm{Cl}^{-1} \mathrm{~d}^{-1}$ (0.01 to $1.61 \mu \mathrm{g} \mathrm{C} \mathrm{l}^{-1} \mathrm{~d}^{-1}$ ), which corresponds to $17 \%$ (1 to $35 \%$ ) of the cyanobacteria standing stock. It therefore appears that the potential grazing effect of ciliates $<20 \mu \mathrm{m}$ on cyanobacteria is at least equivalent to that of nanoflagellates (if $100 \%$ of the nanoflagellates were grazers) or even higher if it is assumed that $50 \%$ of the nanoflagellates are grazers.

\section{Spring and summer food webs in temperate nearshore waters}

Data in the present study support the view that, in temperate nearshore waters, there is a close link between seasonal changes in the size structures of phytoplankton and protozooplankton assemblages. Our observations and the results of path analyses combined with findings from the literature suggest the existence of 2 different food webs corresponding to bloom and summer conditions, respectively (Fig. 7). These 2 webs are based on the sizes of autotrophic cells and of herbivorous protozoa, on the changes in mesozooplankton grazing pressure and, hence, on resulting changes in trophic pathways mediated by protozooplankton. This model is somewhat similar to that of Rivkin et al. (1996), who documented, in sedimenting particulate matter of the Gulf of St. Lawrence, replacement of phytoplankton material (spring bloom) by an equivalent amount of faecal pellets (summer).

During the spring bloom (Fig. 7a), the phytoplankton assemblage mainly consisted of chain-forming diatoms (>5 $\mu \mathrm{m}$ ). Because of their low abundances at this time, mesozooplankton did not exert significant grazing pressure on phytoplankton or protozooplankton and production of faecal pellets was low. Given the weak control by mesozooplankton, large-sized herbivorous a) Spring bloom: phytoplankton and protozooplankton dominated by large forms b) Summer: phytoplankton and protozooplankton dominated by small forms
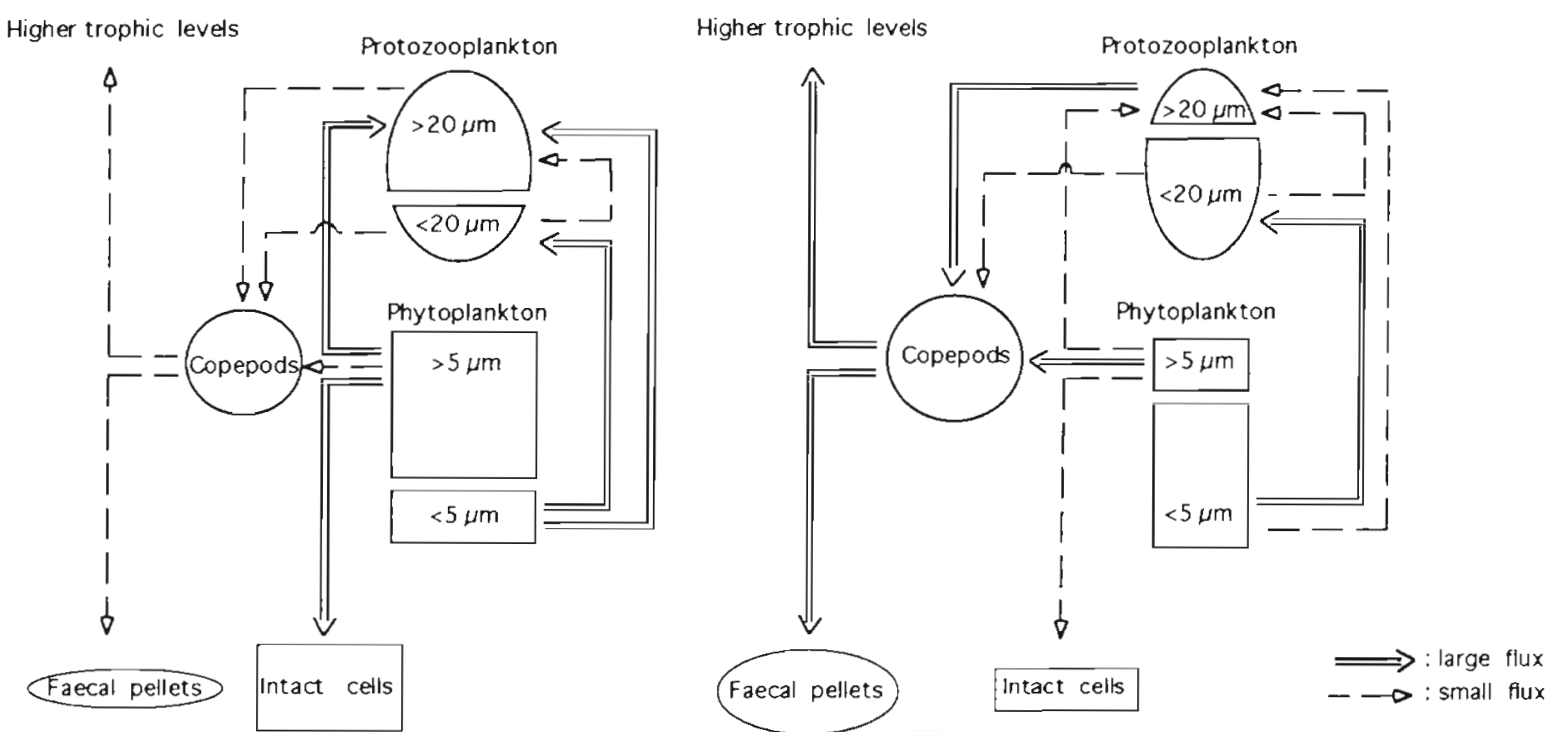

Fig. 7. Conceptual model showing trophic interactions among mesozooplankton (copepods), protozooplankton $(<20$ and $>20 \mu m)$, and phytoplankton $(<5$ and $>5 \mu \mathrm{m})$, for 2 typical seasonal situations in temperate nearshore waters: (a) during the spring phytoplankton bloom, biomasses of large phytoplankton and large protozooplankton are high and concentrations of copepods are low. (b) During summer, phytoplankton and protozooplankton assemblages are dominated by small cells and copepod concentrations reach their seasonal maximum. Areas of geometric figures reflect concentrations and widths of arrows refer to absolute fluxes 
protists $(>20 \mu \mathrm{m})$ feeding on spring bloom phytoplankton developed very high biomasses. However, protozoan grazers did not succeed in controlling the phytoplankton growth and a significant part of the algal biomass sedimented to the bottom at the end of the bloom. During the decline of the bloom, growth of phytoplankton $<5 \mu \mathrm{m}$ was enhanced by the warming of the water (Fig. 5b), these small algae were then exploited (but not controlled) by $<20 \mu \mathrm{m}$ ciliates and. flagellates. This view is supported by the results of path analysis, which showed a strong trophic path from phytoplankton $>5 \mu \mathrm{m}$ to large tintinnids and from phytoplankton $<5 \mu \mathrm{m}$ to small aloricate ciliates and flagellates (Fig. 5b). Thus, only a small part of the primary production was channelled towards higher trophic levels of the pelagic food web, directly to copepods or through protozooplankton.

During summer (Fig. 7b), in contrast with the spring diatom bloom, the phytoplankton assemblage was dominated by ultraplankton $(<5 \mu \mathrm{m})$. Their biomass slightly increased at the end of the bloom, after which it remained relatively constant. At the same time, the abundance of omnivorous copepods and production of faecal pellets were highest. High grazing pressure by omnivorous copepods maintained the biomass of protozooplankton at lower levels than during the spring bloom. The weak correlation coefficients (Table 1) and the absence of significant paths from large phytoplankton to protists during summer (Fig. $5 \mathrm{c}$, d) are consistent with a control of protist abundance by mesozooplankton. Protozoa, especially ciliates, actively grazed on phytoplankton and kept a close coupling with small primary producers. The relative contributions of smallsized ciliates and flagellates $(<20 \mu \mathrm{m})$ strongly increased in the protozooplankton assemblage during summer, because of the small size of autotrophic organisms available and of selective grazing of larger protozoa by copepods. During summer, protozoa, especially ciliates, were therefore an important link in transferring primary production to carnivorous mesozooplankton and, thus, to large metazoans (e.g. fish larvae)

Acknowledgements. Contribution to the programme of GIROQ (Groupe interuniversitaire de recherches océanographiques du Québec). Funding for this research was provided by OPEN, one of the fifteen Networks of Centres of Excellence supported by the government of Canada. Grants to E.T from the Ministère de l'Éducation, de la Recherche et de la Formation de la Communauté Francaise de Belgique, to L.L. from the Natural Science and Engineering Research Council of Canada, and to GIROQ from NSERC and FCAR of Québec were instrumental in the completion of the work. We are grateful to R. Drolet, D. Many, S. Ochman and M. Parent for their valuable help at sea. Special thanks go to $C$. Haurillon, and $E$. Vazquez for their enthusiasm and curiosity dunng the course of the study. We appreciate the helpful comments and suggestions on earlier drafts of this paper provided by $\mathrm{L}$ Johnson, C. Lovejoy, R. B. Rivkin and 3 anonymous reviewers

\section{LITERATURE CITED}

Antia AVN (1991) Microzooplankton in the pelagic food web of the east Greenland Sea and its role in sedimentation processes. PhD thesis, Kiel University, Germany

Bernard C, Rassoulzadegan F (1990) Bacteria or microflagellates as a major food source for marine ciliates: possible implications for the microzooplankton. Mar Ecol Prog Ser $64: 147-155$

Bralewska JM, Witek Z (1995) Heterotrophic dinoflagellates in the ecosystem of the Gulf of Gdansk. Mar Ecol Prog Ser $117: 241-248$

Buskey EJ (1993) Annual pattern of micro- and mesozooplankton abundance and biomass in a subtropical estuary. J Plankton Res 15:907-924

Bustillos-Guzman J, Claustre H, Marty JC (1996) Phaeopigment dynamics and their relationship with the phytoplankton pigment signatures in the Mediterranean sea 1996 Ocean Sciences Meeting, supplement to EOS 76(3) OS117

Campbell L, Carpenter EJ (1986) Estimating the grazing pressure of heterotrophic nanoplankton on Synechococcus spp. using the sea water dilution and selective inhibitor techniques. Mar Ecol Prog Ser 33:121-129

Capriulo GM (1990) Feeding-related ecology of marine protozoa. In: Capriulo GM (ed) Ecology of marine protozoa. Oxford University Press, New York, p 186-257

Capriulo GM (1991) Community grazing in heterotrophic marine protista - session summary. In: Reid PC, Turley $C M$, Burkill PH (eds) Protozoa and their role in marine processes. NATO ASI Series, Springer-Verlag, Berlin, p 205-218

Capriulo GM, Sherr EB, Sherr BF (1991) Trophic behaviour and related community feeding activities of heterotrophic marine protists. In: Reid PC, Turley CM, Burkill PH (eds) Protozoa and their role in marine processes. Nato ASI Series, Springer Verlag, Berlin, p 219-265

Caron DA, Lim EL, Miceli G, Waterbury JB, Valois FW (1991) Grazing and utilisation of chroococcoid cyanobacteria and heterotrophic bacteria by protozoa in laboratory cultures and a coastal plankton community. Mar Ecol Prog Ser 76: $205-217$

Chavez FP. Karl DM, Hebel D, Latasa M. Campbell L. (1995) On the chlorophyll a retention properties of glass-fiber $\mathrm{GF} / \mathrm{F}$ filters. Limnol Oceanogr 40:428-433

Claereboudt M, Côté J, Bonardelli J, Himmelman JH (1994) Seasonal variation in abundance and size structure of phytoplankton in Baie des Chaleurs, southwestern Gulf of St. Lawrence, in relation to physical oceanographic conditions. Hydrobiologia 306:147-157

Coffin RB, Sharp JH (1987) Microbial trophodynamics in the Delaware Estuary. Mar Ecol Prog Ser 41:253-266

Dolan JR, Coats DW (1990) Seasonal abundance of planktonic ciliates and microflagellates in mesohaline Chesapeake Bay waters. Estuar Coast Shelf Sci 31:157-175

Durban EG, Krawlec RW, Smayda TJ (1975) Seasonal studies on the relative importance of different size fractions of phytoplankton in Narragansett Bay (USA). Mar Biol 32: $271-287$

Epstein SS, Shıaris MP (1992) Size-selective grazing of coastal bacterioplankton by natural assemblages of pigmented flagellates, colourless flagellates, and ciliates. Microb Ecol 23:211-225

Fessenden L, Cowles TJ (1994) Copepod predation on phagotrophic ciliates in Oregon coastal waters. Mar Ecol Prog Ser 107:103-111

Gifford DJ (1988) Impact of grazing by microzooplankton in 
the Northwest Arm of Halifax Harbour. Nova Scotia. Mar Ecol Prog Ser 47:249-258

Goldman JC, MCCarthy J, Peavey GD (1979) Growth rate influence on the chemical composition of phytoplankton in oceanic waters. Nature 279:211-215

Hall JA, Barret DP, James MR (1993) The importance of phytoflagellate, heterotrophic flagellate and ciliate grazing on bacteria and picophytoplankton sized prey in a coastal marine environment. J Plankton Res 15:1075-1086

Hansen PJ (1991) Quantitative importance and trophic role of heterotrophic dinoflagellates in a coastal pelagial food web. Mar Ecol Prog Ser 73:253-261

Hansen PJ (1992) Prey size selection, feeding rates and growth dynamics of heterotrophic dinoflagellates with special emphasis on Gyrodinium spirale. Mar Biol 114: $327-334$

Havens KE (1993) An experimental analysis of macrozooplankton, microzooplankton and phytoplankton interactions in a temperate eutrophic lake. Arch Hydrobiol 127: $9-20$

Jacobson DM, Anderson DM (1986) Thecate heterotrophic dinoflagellates: feeding behavior and mechanisms. J Phycol 22:249-258

Jerome CA, Montagnes DJS, Taylor FJR (1993) The effect of quantitative protargol stain and Lugol's and Bouin's fixatives on cell size: a more accurate estimate of cliate species biomass. J Euk Microbiol 40:254-259

JGOFS (1988) Core measurements protocols. Reports of the core measurements working groups. JGOFS report no. 6 . International Council of Scientific Unions, Scientific Committee on Oceanic Research, Kiel

Joint IR, Pomeroy AJ (1986) Photosynthetic characteristics of nanoplankton and picoplankton from the surface mixed layer. Mar Biol 92:465-474

Jones RI (1994) Mixotrophy in planktonic protists as a spectrum of nutritional strategies. Mar Microb Food Webs 8: $87-96$

Lacroix G, Filteau G (1970) Les fluctuations quantitatives du zooplancton de la Baie-des-Chaleurs (Golfe du Saint-Laurent) II. Composition des copépodes et fluctuations des copépodes du genre Calanus. Nat Can (Que) 97:711-748

Lacroix G, Filteau G (1971) Les fluctuations quantitatives du zooplancton de la Baie-des-Chaleurs (Golfe du Saint-Laurent) III. Fluctuations des copépodes autres que Calanus. Nat Can (Que) 98:775-813

Landry MR. Hassett RP (1982) Estimating the grazing impact of marine micro-zooplankton. Mar Biol 67:283-288

Larsen J, Sournia A (1991) The diversity of heterotrophic dinoflagellates. In: Patterson DJP, Larsen J (eds) The biology of free-living heterotrophic flagellates. Systematics Association, Spec Vol 45. Clarendon Press, Oxford, p 313-331

Legendre L, Legendre P (1984) Écologie numérique, Tome 2. La structure des données écologiques, 2e éd. Collect Écol 13. Masson, Paris

Legendre P, Vaudor A (1991) The R package for multivariate data analysis. Département des sciences biologiques, Université de Montréal, Canada

Lessard EJ (1991) The trophic role of heterotrophic dinoflagellates in diverse marine environments. Mar Microb Food Webs 5:49-58

Lessard EJ, Swift E (1985) Species-specific grazing rates of heterotrophic dinoflagellates in oceanic waters. Mar Biol 87:289-296

Li WKW (1995) Composition of ultraphytoplankton in the central North Atlantic. Mar Ecol Prog Ser 122:1-8

Lund JWG, Kipling C, Lecren ED (1958) The inverted micro- scope method of estimating algal numbers and the statustical basis of estimations by counting. Hydrobiologia 11 $143-170$

Lynn DH, Montagnes DJS (1991) Global production of heterotrophic marne planktonic ciliates. In: Reid PC, Turley $\mathrm{CM}$, Burkill PH (eds) Protozoa and their role in marine processes. Nato ASI Series, Springer Verlag, Berlin, p 281-308

McManus GB, Ederington-Cantrell MC (1992) Phytoplankton pigments and growth rates, and microzooplankton grazing in a large temperate estuary. Mar Ecol Prog Ser 87 $77-85$

Montagnes DJS, Lynn DH (1991) Taxonomy of choreotrichs, the major marine planktonic ciliates, with emphasis on the aloricate form. Mar Microb Food Webs 5:59-74

Neuer S, Cowles T (1994) Protist herbivory in the Oregon upwelling system. Mar Ecol Prog Ser 113:147-162

Ohman MD, Runge JA (1994) Sustained fecundity when phytoplankton resources are in short supply: omnivory by Calentis finmarchicus in the Gulf of St. Lawrence. Limnol Oceanogr 39:21-36

Paffenhofer GA (1993) On the ecology of marine cyclopoid copepods (Crustacea, Copepoda). J Plankton Res 15 $37-55$

Painting SJ, Moloney CL, Probyn TA, Tibbles B (1992) Microheterotrophic pathways in the southern Benguela upwelling system. In: Payne AIL, Brink KH, Mann KH, Hilborn R (eds) Benguela trophic functioning. Special publication of South African Journal of Marine Science 12: $527-543$

Paranjape MA (1990) Microzooplankton herbivory on the Grand Bank (Newfoundland, Canada): a seasonal study. Mar Biol 107:321-328

Parsons TR, Maita Y, Lalli CM (1984) A manual of chemical and biological methods for seawater analysis. Pergamon Press, Toronto

Pierce RW: Turner JT (1992) Ecology of planktonic ciliates in marine food webs. Rev Aquat Sci 6:139-181

Putt M. Stoecker DK (1989) An experimentally determined carbonvolume ratio for marine 'oligotrichous' ciliates from estuarine and coastal waters. Limnol Oceanogr 34 $1097-1103$

Rassoulzadegan F, Laval-Peuto M, Sheldon RW (1988) Partitioning of the food ration of marine clliates between picoand nanoplankton. Hydrobiologia 159:75-88

Reid PC. Turley CM, Burkill PH (1991) Protozoa and their role in marine processes. Nato ASI Series, Springer Verlag, Berin

Riegman R, Kuipers BR, Noordeloos AAM, Witte HJ (1993) Size-differential control of phytoplankton and the structure of plankton communities. Neth J Sea Res 31:255-265

Rivkin RB, Legendre L, Deibel D, Tremblay JE, Klein B, Croker K, Roy S. Silverberg N, Lovejoy C, Mesplé F, Romero $N$, Anderson $M R$, Matthews $P$, Savenkoff $C$, Vezina $A$, Therriault JC. Wesson J, Berubé C, Ingram RG (1996) Vertical flux of biogenic carbon in the ocean: is there food web control? Sclence 272:1163-1166

Rublee PA. Gallegos CL (1989) Use of fluorescently labelled algae (F.AA) to estimate microzooplankton grazing. Mar Ecol Prog Ser 51:221-227

Sanders $\bar{R} W$, Wickham SA (1993) Planktonic protozoa and metazod: predation, food quality and population control. Mar Microb Food Webs 7:197-223

Sheldon RW, Nival P, Rassoulzadegan F (1986) An experimental investigation of a flagellate-clliate-copepod food chain with some observations relevant to the linear biomass hypothesis. Limnol Oceanogr 31:184-188 
Sherr EB, Sherr BF (1994) Bacterivory and herbivory: key roles of phagotrophic protists in pelagic food webs. Microb Ecol 28:223-235

Simek K, Macek M, Pernthaler J, Straskrabova V, Psenner R (1996) Can freshwater planktonic ciliates survive on a diet of picoplankton? J Plankton Res 18:597-613

Sime-Ngando T, Gosselin M. Roy S, Chanut JP (1995) Significance of planktonic ciliated protozoa in the lower St. Lawrence Estuary: comparison with bacterial, phytoplankton, and particulate organic carbon. Aquat Microb Ecol 9:243-258

Smetacek V (1981) The annual cycle of protozooplankton in the Kıel Bight. Mar Biol 63:1-11

Sokal RR, Rolf FJ (1981) Biometry: the principles and practice of statistics in biological research, 2nd edn. WH Freeman \& Co, San Francisco

Stoecker DK (1991) Mixotrophy in marine planktonic ciliates: physiological and ecological aspects of plastid-retention by oligotrichs. In: Reid PC, Turley CM, Burkill PH (eds) Protozoa and their role in marine processes, 1, Nato ASI Series. Springer Verlag, Amsterdam, p 161-179

Stoecker DK, Capuzzo JMD (1990) Predation on protozoa: its importance to zooplankton. J Plankton Res 12:891-908

Tamigneaux $E$, Vazquez $E$, Mingelbier $M$, Klein $B$, Legendre L (1995) Environmental control of phytoplankton assemblages in nearshore marine waters, with special emphasis on phototrophic ultraplankton. J Plankton Res 17:1421-1447

Vaqué D. Pace ML, Findlay S, Lints D (1992) Fate of bacterial production in a heterotrophic ecosystem: grazing by pro-

This article was submitted to the editor tists and metazoans in the Hudson Estuary. Mar Ecol Prog Ser 89:155-163

Verity PG (1991) Measurements and simulation of prey uptake by marine planktonic ciliates fed plastidic and aplastidic nanoplankton. Limnol Oceanogr 36:740-750

Verity PG, Stoecker DK, Sierackı ME, Burkill PH. Edwards ES, Tronzo CR (1993) Abundance, biomass and distribution of heterotrophic dinoflagellates during the North Atlantic spring bloom. Deep Sea Res 40:227-244

Weisse T (1991) The annual cycle of heterotrophic freshwater nanoflagellates: role of bottom-up versus top-down control. J Plankton Res 13:167-185

Weisse T, Scheffel-Möser U (1990) Growth and grazing loss rates in single-celled Phaeocystis sp. (Prymnesiophyceae). Mar Biol 106:153-158

Weisse T, Scheffel-Möser U (1991) Uncoupling the microbial loop: growth and grazing loss rates of bacteria and heterotrophic nanoflagellates in the North Atlantic. Mar Ecol Prog Ser 71:195-205

Welschmeyer NA, Copping AE, Vernet $M$, Lorenzen $C J$ (1984) Diel fluctuation in zooplankton grazing rate as determined from the downward vertical flux of pheopigments. Mar Biol 83:263-270

Wiackowski K, Brett MT, Goldman CR (1994) Differential effects of zooplankton species on ciliate community structure. Limnol Oceanogr 39:486-492

Yentsch CS, Menzel DW (1963) A method for the determination of chlorophyll and phaeophytin by fluorescence. Deep Sea Res 10:221-231

Manuscript first received: April 3, 1995

Revised version accepted: October 14, 1996 